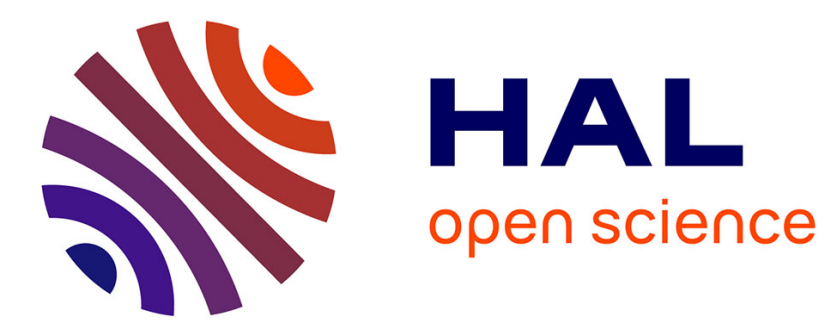

\title{
Nitrogen solubility in basaltic silicate melt - Implications for degassing processes
}

\author{
Fabien Bernadou, Fabrice Gaillard, Evelyn Füri, Yves Marrocchi, Aneta
} Slodczyk

\section{- To cite this version:}

Fabien Bernadou, Fabrice Gaillard, Evelyn Füri, Yves Marrocchi, Aneta Slodczyk. Nitrogen solubility in basaltic silicate melt - Implications for degassing processes. Chemical Geology, 2021, pp.120192. 10.1016/j.chemgeo.2021.120192 . insu-03186359

\section{HAL Id: insu-03186359 \\ https://hal-insu.archives-ouvertes.fr/insu-03186359}

Submitted on 31 Mar 2021

HAL is a multi-disciplinary open access archive for the deposit and dissemination of scientific research documents, whether they are published or not. The documents may come from teaching and research institutions in France or abroad, or from public or private research centers.
L'archive ouverte pluridisciplinaire HAL, est destinée au dépôt et à la diffusion de documents scientifiques de niveau recherche, publiés ou non, émanant des établissements d'enseignement et de recherche français ou étrangers, des laboratoires publics ou privés. 


\section{Journal Pre-proof}

Nitrogen solubility in basaltic silicate melt - Implications for degassing processes

Fabien Bernadou, Fabrice Gaillard, Evelyn Füri, Yves Marrocchi, Aneta Slodczyk

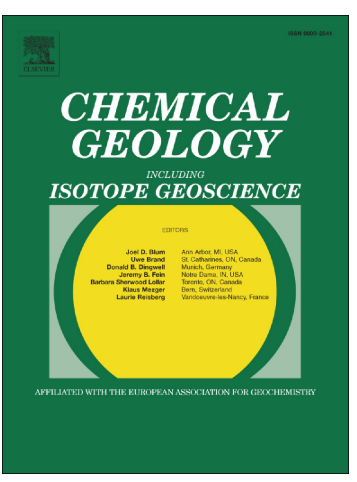

$\begin{array}{ll}\text { PII: } & \text { S0009-2541(21)00136-4 } \\ \text { DOI: } & \text { https://doi.org/10.1016/j.chemgeo.2021.120192 } \\ \text { Reference: } & \text { CHEMGE 120192 }\end{array}$

To appear in: $\quad$ Chemical Geology

Received date: $\quad 6$ July 2020

Revised date: $\quad 3$ February 2021

Accepted date: $\quad 21$ March 2021

Please cite this article as: F. Bernadou, F. Gaillard, E. Füri, et al., Nitrogen solubility in basaltic silicate melt - Implications for degassing processes, Chemical Geology (2021), https://doi.org/10.1016/j.chemgeo.2021.120192

This is a PDF file of an article that has undergone enhancements after acceptance, such as the addition of a cover page and metadata, and formatting for readability, but it is not yet the definitive version of record. This version will undergo additional copyediting, typesetting and review before it is published in its final form, but we are providing this version to give early visibility of the article. Please note that, during the production process, errors may be discovered which could affect the content, and all legal disclaimers that apply to the journal pertain.

C 2021 Published by Elsevier. 


\title{
Chemical geology
}

\section{Manuscript draft}

Title: Nitrogen solubility in basaltic silicate melt - Implications for degassing processes

Article Type: Research paper

Keywords: Nitrogen, Solubility, oxygen fugacity, IHPV, SIMS

\begin{abstract}
The distribution of nitrogen between the different terrestrial reservoirs (core-mantleatmosphere) and how this may have changed from the earliest, lanetary stages is uncertain. In particular, the primordial degassing processes of the magma ocean ar. its role in the formation of the atmosphere remains to be quantified. Since no geologici sal uples can capture this early degassing process, we need to go through the thermodynamic . « veılng of the nitrogen solubility in silicate melt. We hence performed experiments on basaltic sin. nlec at fluid saturation in the $\mathrm{C}-\mathrm{H}-\mathrm{O}-\mathrm{N}$ system, using an Internally Heated Pressure Vessel (IHPV) a. I Piston Cylinder (PC) in the pressure range $0.8 \mathrm{kbar}$ to $10 \mathrm{kbar}$, temperature between $12\left(\mathrm{O}\right.$ a.d $1300^{\circ} \mathrm{C}$, and a wide range of $\mathrm{fO}_{2}$ conditions from IW+4.9 to IW-4.7 (Iron-Wustite redox bu"er). The nitrogen concentration in the quenched silicate melts at fluid saturation was analv:- $\gamma$ by secondary ion mass spectrometry (SIMS), and the speciation of the dissolved $\mathrm{C}-\mathrm{O}-\mathrm{H}$ species , vas determined by Fourier transform infrared spectroscopy (FTIR). We identified two nitrogen $\mathrm{s}_{\mathrm{r}}$ 'cies in the silicate melt: $\mathrm{N}_{2}$ dominating at $\mathrm{fO}_{2}>\mathrm{IW}$ and $\mathrm{N}^{3-}$ at lower $\mathrm{fO}_{2}$. Using these data and a $d$ tabase constraining nitrogen concentration at fluid saturation from 1 bar to $10 \mathrm{kbar}$ pressure, .e calibrated a solubility law for nitrogen in basalts defining its P-T- $\mathrm{fO}_{2}$ dependences. This $\ldots$ ndel expands the model of Libourel et al. (2003) to high pressure and higher $\mathrm{C}-\mathrm{O}-\mathrm{H}$ activities. It $\neg n \sim$ ? used to investigate the nitrogen degassing processes for different pressure, temperature ar. $\mathrm{I}_{\mathrm{O}}$, conditions relevant to planetary accretion and modern volcanism.
\end{abstract}




\title{
Nitrogen solubility in basaltic silicate melt - Implications for degassing processes
}

\author{
Fabien Bernadou ${ }^{*, 1}$, Fabrice Gaillard ${ }^{1}$, Evelyn Füri ${ }^{2}$, Yves Marrocchi ${ }^{2}$, Aneta Slodczyk ${ }^{1}$ \\ ${ }^{1}:$ Institut des Sciences de la Terre d'Orléans, CNRS/Université d'Orléans/BRGM, 1a rue de \\ la Férollerie 45071, Orléans cedex 2, France \\ 2 : Université de Lorraine, CNRS, CRPG, F-54000 Nancy, Fran', ? \\ *: Corresponding author e-mail address: fabien.bernadou $\left(\rho \sim n_{1} \sim\right.$ urleans.fr
}

\section{Abstract}

The distribution of nitrogen betw' $\backsim$ ine different terrestrial reservoirs (core-mantleatmosphere) and how this $m_{c}$ ! have changed since the earliest planetary stages is uncertain. In particular, the orin ardial degassing processes of the magma ocean and its role in the formation of tri aimr,sphere remains to be quantified. Since no geological samples can capture this early degassing process, we need to go through the thermodynamic modelling of the nitrogen solubility in silicate melt. We hence performed experiments on basaltic samples at fluid saturation in the $\mathrm{C}-\mathrm{H}-\mathrm{O}-\mathrm{N}$ system, using an Internally Heated Pressure Vessel (IHPV) and Piston Cylinder (PC) in the pressure range 0.8 kbar to $10 \mathrm{kbar}$, temperature between 1200 and $1300^{\circ} \mathrm{C}$, and a wide range of $\mathrm{fO}_{2}$ conditions from $\mathrm{IW}+4.9$ to IW-4.7 (IW standing for the Iron-Wustite redox buffer). The nitrogen concentration in the quenched silicate melts at fluid saturation was analysed by secondary ion mass spectrometry 
(SIMS), and the speciation of the dissolved $\mathrm{C}-\mathrm{O}-\mathrm{H}$ species was determined by Fourier transform infrared spectroscopy (FTIR). We identified two nitrogen species in the silicate melt: $\mathrm{N}_{2}$ dominating at $\mathrm{fO}_{2}>\mathrm{IW}$ and $\mathrm{N}^{3-}$ at lower $\mathrm{fO}_{2}$. Using these data and a database constraining nitrogen concentration at fluid saturation from 1 bar to 10 kbar pressure, we calibrated a solubility law for nitrogen in basalts defining its $\mathrm{P}-\mathrm{T}-\mathrm{fO}_{2}$ dependences. This model expands the model of Libourel et al. (2003) to high pressure and higher $\mathrm{C}-\mathrm{O}-\mathrm{H}$ activities. It can be used to investigate the nitrogen degassing processes for different pressure, temperature and $\mathrm{fO}_{2}$ conditions relevant to pic netary accretion and modern volcanism.

Key Words: Nitrogen, solubility, degassin,$~\urcorner x$, ren fugacity, IHPV, SIMS

\section{Introduction}

Whereas other volatile cimponents such as $\mathrm{H}_{2} \mathrm{O}$ or $\mathrm{CO}_{2}$ have been intensively

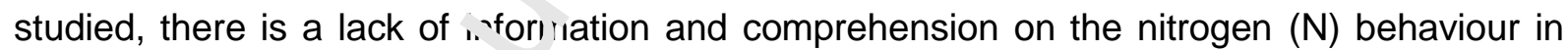
Earth's interior during ine various stages of its formation. Nitrogen, however, dominates the current Earth's atmosphere and its availability for life molecules like amino acids -as highlighted by the experiment of Miller and Urey (Miller, 1953)- is probably an important prerequisite for habitability (Catling and Zahnle, 2020). Earth's nitrogen shows isotopic compositions close to those of enstatite chondrites, suggesting it was probably delivered during the main accretion stage (Marty, 2012). $\mathrm{N}$ must have been subsequently processed through the magma ocean stage and then possibly released via planetary magmatism during 
the Hadean and Archean eons. Understanding the timing of nitrogen degassing is of primordial importance to capture the evolution of Earth's atmosphere (Zahnle et al., 2010). Although $\mathrm{N}_{2}$ partial pressure and isotopic composition of the Archean atmosphere have been reported based on $\mathrm{N}$ analyses of fluid inclusions trapped in quartz (Marty et al., 2013), the $\mathrm{N}$ behaviour during the magma ocean and earliest terrestrial volcanism stages is still underconstrained.

According to the literature, the degassing of nitrogen frorı, 7 silicate melt is enhanced by oxidizing conditions (Libourel et al., 2003; Boulliung eı І., 2020). On the other hand,

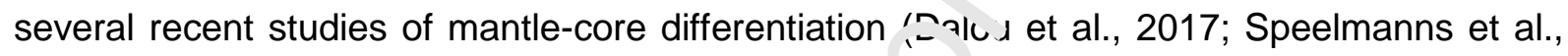
2019) have highlighted that nitrogen can be moderaıely siderophile at oxygen fugacity closed to Iron-Wüstite redox buffer (IW-2), while :- is nagmatophile (ie. High affinity for the silicate melt phase) under more reduced conditions. This implies that from the most reduced to the most oxidizing conditions nitrogen Le' laviour must evolve from magmatophile to siderophile and then atmophile. Given this $g_{1}$, at diversity of possible $N$ behaviour, tight and precise experimental constraints art $n$;eded to decipher the fate of nitrogen during these earliest differentiation events.

$\mathrm{N}$ solubility has been experimentally investigated in minerals (Li et al., 2013; Yoshioka et al., 2018) as well as silicate melts, fluids and metal alloys (Dalou et al., 2017; Kadik et al., 2015; Roskosz et al., 2013; Speelmanns et al., 2018, 2019; Grewal et al., 2019; Dalou et al., 2019a; Mosenfelder et al., 2019). In theory, all these data could be combined to address $\mathrm{N}$ magmatic degassing processes using thermodynamic modelling. Gaillard and Scaillet (2014) used the solubility model of Libourel et al. (2003) to predict degassing in the C-H-O-N-S 
system, but no experimental verification of the validity of this model at pressure superior then 1 bar and in $\mathrm{H}$-bearing system exists. In this study, we thus focus on magmatic nitrogen in order to capture the fluid-melt equilibria governing nitrogen degassing at medium pressure (0.8 to $2.4 \mathrm{kbar})$ and medium temperature $\left(1200\right.$ to $\left.1300^{\circ} \mathrm{C}\right)$.

According to Libourel et al. (2003), the nitrogen speciation in silicate melt can be split in two domains. For $\mathrm{fO}_{2}$ more oxidizing than the Iron-Wüstite (IW) redox buffer, nitrogen is physically dissolved in the silicate melt and its concentration uinends mainly on pressure (i.e., nitrogen partial pressure). Under these conditions $I_{c}\left(\mathbb{I}^{0}\right.$ valence) is the dominant nitrogen species and its concentration in the silicate .... in is usually low (i.e., $\ll 100$ ppm; Libourel et al., 2003). For oxygen fugacity more roduced inan the IW redox buffer, nitrogen is chemically dissolved in the silicate melt; it a ncentration is high (>>100 ppm) and strongly correlated with $\mathrm{fO}_{2}$ variations. The dominan shemically dissolved species is described as $\mathrm{N}^{3-}$ in a hydrogen free system (Libourel e'. a.., 2003), while $\mathrm{NH}_{3}$ species $\left(\mathrm{N}^{3-}\right.$ valence) have been identified in H-bearing system (Kádik et al., 2015; Dalou et al., 2019b; Grewal et al., 2020; Mosenfelder et al., 2019) at :-in . pressure. Some other minor species have been suggested such as $\mathrm{CN}^{-}$(Dalou et a. 2019b) or $\mathrm{NO}^{-}$(Roskosz et al., 2006). Therefore, in addition to $\mathrm{N}^{3-}$, the potential role of $\mathrm{CN}^{-}, \mathrm{NO}^{-}$or $\mathrm{NH}_{3}$ species in the solubility of nitrogen in basaltic system must be determined.

Considering the fluid phases at high pressure and high temperature, the nitrogen speciation in a N-H-O system mainly involves $\mathrm{N}_{2}$ and $\mathrm{NH}_{3}$ (Chen et al., 2019; Li and Keppler, 2014). The ratio between these two species depends on various parameters such as pressure, temperature, $\mathrm{fO}_{2}$ and total nitrogen concentration in the fluid (Chen et al., 2019; $\mathrm{Li}$ 
and Keppler, 2014). However, these studies report contrasting results, likely due to the different techniques used for characterizing the samples (in situ vs. post-mortem). According to Chen et al. (2019), it appears that post-mortem studies tend to overestimate the $\mathrm{NH}_{3}$ stability domain, implying that at most magmatic conditions (low $\mathrm{P}$, high $\mathrm{T}$ ), $\mathrm{N}_{2}$ should be the major $\mathrm{N}$-species in the fluid (e.g $\mathrm{P}<5 \mathrm{kbar}$ and $\left.\mathrm{T}>1000^{\circ} \mathrm{C}\right)$.

Currently, the study by Libourel et al., 2003 remains the reference when it comes to modeling the behavior of nitrogen between silicate melt and fiui- phase as it links nitrogen fugacity in the fluid to $\mathrm{N}$ contents in the silicate melt. How $=\mathrm{vc}^{\circ}$, this model uses low pressure data (i.e. $1 \mathrm{~atm}$ ) in a $\mathrm{H}$-free system. The study by $\mathrm{L}^{\prime}{ }^{+}{ }^{+}$a.i., 2015 at medium pressure (i.e.> $1 \mathrm{kbar}$ ) is interesting because it provides data on Nvsoluuility in $\mathrm{H}$-bearing systems but their interpretatation being based on empirical fl. ia- nelt partition coefficient, prevents a link with $\mathrm{N}$ fugacity and does not permit of Libourel st al. (2003) solubility model. There therefore remains a large shadow area conce $n$ 'nc the medium and high pressure modeling.

In this study, we inve stigu'e nitrogen solubility in basaltic silicate melt, i.e., the nitrogen content in the quers $h^{\prime}, d$ silicate melt at fluid saturation. We performed a series of experiments at interme ${ }^{\prime}$ iate pressure $(0.8$ to $10 \mathrm{kbar})$, high temperature $\left(1200^{\circ} \mathrm{C}\right.$ and $\left.1300^{\circ} \mathrm{C}\right)$ and over a wide range of $\mathrm{fO}_{2}(\mathrm{IW}-4.72$ to $\mathrm{IW}+4.91)$ in the $\mathrm{C}-\mathrm{H}-\mathrm{O}-\mathrm{N}$ system with a starting material of basaltic composition. By combining our results and the available literature data, we calibrate a nitrogen solubility model operating from surficial to upper mantle conditions. 


\section{Experimental and analytical techniques}

\subsection{Starting material}

The starting product is a natural basalt of Monte Sagnolo (Etna, Sicily; Gennaro et al., 2019). The basalt was crushed in an agate mortar with ethanol. The obtained powder was melted at 1 bar and $1400^{\circ} \mathrm{C}$ for 1 hour in a Pt crucible. The obtained gla - was crushed and melted a second time in order to get a homogenous chemical comr: aliun. After a last fine crushing, the powders were stored away from moisture at $120^{\circ} \mathrm{C}$ iा ? stove. Nitrogen was added using different sources in the experimental charges $\left(T a b^{\prime}+1\right)$. aqueous solution of ammonia $\left(\mathrm{NH}_{3}\right.$ $32 \%)$, nitric acid $\left(\mathrm{HNO}_{3} 65 \%\right)$ and dry powdte of sllicon $\left(\mathrm{Si}_{3} \mathrm{~N}_{4}\right)$ and iron nitride $\left(\mathrm{Fe}_{x} \mathrm{~N}\right)$ were

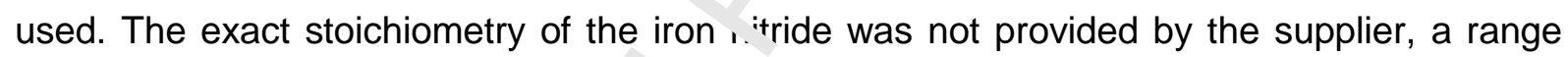
between $\mathrm{Fe}_{2} \mathrm{~N}$ and $\mathrm{Fe}_{4} \mathrm{~N}$ is indicate 1. $\therefore$ ' conducted X-Ray Diffraction (XRD) and elemental analyser analysis indicating in эverage stoichiometry of $\mathrm{Fe}_{3,5} \mathrm{~N}$. For the experimental charges where nitrogen $w_{c}$ s added as aqueous solution, we added graphite in order to dehydrate and buffer thı carbon activity in the charges following the equilibria:

$$
\begin{gathered}
\mathrm{H}_{2} \mathrm{O}+\mathrm{C}=\mathrm{H}_{2}+\mathrm{CO} \\
2 \mathrm{H}_{2} \mathrm{O}+\mathrm{C}=2 \mathrm{H}_{2}+\mathrm{CO}_{2}
\end{gathered}
$$

For the charges where we added nitrogen as solids, we used two nitride powders. $\mathrm{Si}_{3} \mathrm{~N}_{4}$ was used as reducing agent (Dalou et al., 2017) following the reaction: 


$$
\mathrm{Si}_{3} \mathrm{~N}_{4}+3 \mathrm{O}_{2} \rightarrow 3 \mathrm{SiO}_{2}+2 \mathrm{~N}_{2}
$$

In our cases the reaction involves the following components (Dalou et al., 2017):

$$
6 \mathrm{FeO}+\mathrm{Si}_{3} \mathrm{~N}_{4} \rightarrow 6 \mathrm{Fe}+3 \mathrm{SiO}_{2}+2 \mathrm{~N}_{2}
$$

This resulted in glasses being depleted in $\mathrm{FeO}$, enriched in $\mathrm{SiO}_{2}$ and forming $\mathrm{Fe}$ metal alloys.

\subsection{Experimental techniques}

Samples were loaded in AuPd and Pt capsu'?s. The various nitrogen sources were mixed with the basalt powders and graphite for $h\lrcorner$ ( harges with aqueous solution. Palladium and iridium powders were also mixed : ith the starting products to create $\mathrm{Fe}-\mathrm{Pd}$ and Fe-Ir alloys as $\mathrm{fO}_{2}$ sensors in the capsules.

We investigated the nircen behaviour in silicate melt using two different experimental setups.

We used the int rna ly heated pressure vessel equipped with drop quench at the Earth Sciences Institute uf Orleans (lacono-Marziano et al., 2009). Within the furnace heated by molybdenum wires, the temperature is monitored by two $\mathrm{Pt}$ thermocouples. A platinum/rhenium quench wire was used as hanging wire. The temperature of most experiments was $1200^{\circ} \mathrm{C}$, while for the experiment (AR5SiNFeN, AR5SiNFeNx2, PCR2SiNFeN), with nitrogen added as a mix of $\mathrm{Fe}_{3,5} \mathrm{~N}$ and $\mathrm{Si}_{3} \mathrm{~N}_{4}$, the temperature was $1300^{\circ} \mathrm{C}$ in order to avoid nucleation of olivine and clinopyroxene (Table 1). These experiments were conducted under gas pressure. The gas was composed of a mixture of 
argon and hydrogen. Between the different runs, we changed the hydrogen fraction of the mixed gas in order to control the oxygen fugacity following this reaction (Gaillard et al., 2003):

$$
\mathrm{H}_{2}+\frac{1}{2} \mathrm{O}_{2}=\mathrm{H}_{2} \mathrm{O}
$$

One experiment was carried out in a half-inch piston cvlinder assembly at a pressure of $10 \mathrm{kbar}(1 \mathrm{GPa})$ and a temperature of $1300^{\circ} \mathrm{C}$ (Table 1) In starting basalt was placed into a AuPd capsule and doped in nitrogen with a mi: if $\mathrm{F}_{3,5} \mathrm{~N}$ and $\mathrm{Si}_{3} \mathrm{~N}_{4}$ powders. The capsule was contained in an alumina sleeve and vas sandwiched between a top and a bottom alumina plug. Temperature was mor.tc red by two PtRh (platinum-rhodium) thermocouples. The alumina sleeve was placed in an assemblage composed of a succession of graphite pyrex and talc c, linders.

\subsection{Analytical technic .es}

\subsubsection{Electron microprobe analysis (EPMA)}

EPMA analyses aimed at obtaining the chemical composition of silicate glass, minerals (olivines, clinopyroxenes) and metal alloys. Two different programs were used, one for analysis of the silicate glasses and the second one for the analysis of the iron alloys. The list of analysed elements of the two programs are listed in the Table 2 . The setting for analysis was $15 \mathrm{kV}$ and a current of $10 \mathrm{nA}$. Focused and defocused beams $(5,10,20 \mu \mathrm{m})$ 
were used depending on the analysed phase (resp. alloy and glass). The counting time for each component varied with their concentrations, more the element was concentrated in the silicate glass least the counting time was (few seconds).

\subsubsection{Infrared analysis}

The $\mathrm{H}_{2} \mathrm{O}$ and $\mathrm{CO}_{2}$ concentrations were determined by transmission Fourier Transform Infrared Spectroscopy (lacono-Marziano et al., 2012; Shi hkı a et al., 2010) on doubly polished samples with the thicknesses varying betw€ ə, \&r to $130 \mu \mathrm{m}$. The micro-FTIR

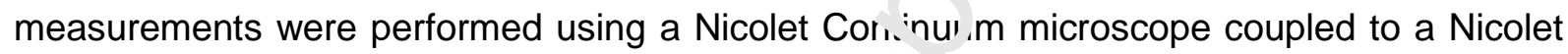
6700 FTIR spectrometer. The device is ec upr ed with Globar light source, XT-KBr beamsplitter, liquid $\mathrm{N}_{2}$ cooled MCT-A dc 'ec ${ }^{+} \mathrm{Jr}$, 32x infinity corrected Schwarzschild objective matching to $32 x$ condenser. The specu? were recorded between $6000-1200 \mathrm{~cm}^{-1}$ with $\mathrm{CaF}_{2}$ support and 4000-650 $\mathrm{cm}^{-1}$ with 'va $\mathrm{va}^{-}$support in order to detect $\mathrm{H}_{2} \mathrm{O}(3500,4500$ and 5200 $\left.\mathrm{cm}^{-1}\right)$ and $\mathrm{CO}_{2}\left(1515-1430 \mathrm{cr}^{-1}{ }^{-1}\right.$ ) bsorption bands, respectively.

\subsection{3. $\mathrm{fO}_{2}$ determination}

Oxygen fugacity $\left(\mathrm{fO}_{2}\right)$ is an important parameter controlling the nitrogen behaviour in silicate melts (Boulliung et al., 2020; Dalou et al., 2019b; Grewal et al., 2020; Libourel et al., 2003; Speelmanns et al., 2019). Here, we use three techniques to determine the experimental $\mathrm{fO}_{2}$ conditions. The sensor technique (Taylor et al., 1992), measuring the $\mathrm{fO}_{2}$ at water saturation, uses two pellets of a Nickel Palladium or Cobalt Palladium alloy with zircon 
powder and 10-20 mg of distilled water (Gaillard et al., 2003). We call this parameter "external $\mathrm{fO}_{2}$ " because it is measured in separate platinum capsule. This external $\mathrm{fO}_{2}$ does not correspond to the $\mathrm{fO}_{2}$ seen by each sample in their own capsule but it represents the $\mathrm{fO}_{2}$ of a virtual sample in which water activity would be 1 .

In order to account for the fact that water activity in our samples was less than 1 , the $\mathrm{fO}_{2}$ was calculated with the equilibrium (5). The law mass action for this equilibrium allows the $\mathrm{fO}_{2}$ prevailing in each experimental charge to be related to the exper. nental $\mathrm{fH}_{2} \mathrm{O}$ and $\mathrm{fH}_{2}$.

$$
\begin{gathered}
K_{5}=\frac{f_{\mathrm{H}_{2} \mathrm{O}}^{\text {melt }}}{f_{\mathrm{H}_{2}}^{\text {melt }} \cdot f \mathrm{O}_{2}^{\frac{1}{2}}} \\
\log \mathrm{fO}_{2}=2 \times\left(\log f^{\prime}, \mathrm{C}-\log K_{5}-\log f \mathrm{H}_{2}\right)
\end{gathered}
$$

Water fugacity $\left(\mathrm{fH}_{2} \mathrm{O}\right)$ is calculated $u s \mathrm{nc}$ the model of (lacono-Marziano et al., 2012) and the water content in silicate glas: ?s (-able 3). We estimated the precision on $\mathrm{fO}_{2}$ using this method as:

$$
\Delta \log f \cup_{2}=\frac{2}{\ln (10)} * \frac{f H_{2}}{f H_{2} O} * \sqrt{\frac{\Delta f H_{2} O^{2}}{f H_{2}{ }^{2}}+\frac{f H_{2} O^{2} * \Delta f H_{2}{ }^{2}}{f H_{2}{ }^{4}}}
$$

In order to directly probe the "internal $\mathrm{fO}_{2}$ " specific to each sample, we used metal-silicate equilibria implying the $\mathrm{fO}_{2}$.

$$
\mathrm{Fe}+\frac{1}{2} \mathrm{O}_{2}=\mathrm{FeO}
$$


Oxygen fugacity can be calculated from the equilibrium (9) involving the activity of $\mathrm{FeO}$ in the silicate melt, the activity of $\mathrm{Fe}$ in the alloy and the equilibrium constant $\mathrm{K}_{9}$ (Gaillard et al., 2003).

$$
K_{9}=\frac{a_{\mathrm{FeO}}^{\mathrm{melt}}}{a_{\mathrm{Fe}}^{\text {alloy }} \cdot \mathrm{fO}_{2}^{1 / 2}}
$$

From the equilibrium constant and with $a_{\mathrm{FeO}}^{\text {melt }}=\gamma_{\mathrm{FeO}}^{\text {melt }} \cdot X_{\mathrm{FeO}}^{\text {melt }}$ and $a_{\mathrm{Fe}}^{\text {alloy }}=\gamma_{\mathrm{Fe}}^{\text {alloy }} \cdot X_{\mathrm{Fe}}^{\text {alloy }}$ the $\mathrm{fO}_{2}$ is calculated with the equation (Medard et al., 2008).

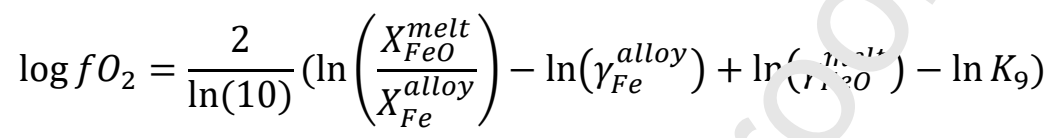

The alloys in our experiment were mainly iron palladiu. (Fe-Pd) and iron iridium (Fe-Ir), with iron concentrations higher than $90 \%$ for th.e most reduce samples (AR5SiNFeN, AR5SiNFeNx2, PCR2SiNFeN see Tablr, 2) Tr心 activity coefficient ( $\mathrm{Y}$ ) of iron for the Fe-Ir alloy was determined using equatior from Vioodland and O'Neill, 1997, for the Fe-Pd alloy, the activity coefficient of Fe was ta'ie, from (Aukrust and Muan, 1962). The equation used for the propagation of uncertaint: ' $\mathrm{s}$ fo, the internal $\mathrm{fO}_{2}$ calculations is:

$$
\Delta \log \mathrm{fO}_{2}=\mathrm{in}_{\mathrm{n}(10)} \frac{\llcorner}{a F e O} * \sqrt{\frac{\Delta a F e O^{2}}{a F e^{2}}+\frac{a F e O^{2} * \Delta a F e^{2}}{a F e^{4}}}
$$

\subsubsection{Volatiles in the glasses and composition of the fluid phase}

Knowledge of the nitrogen pressure $P\left(N_{2}\right)$ or fugacity $f N_{2}$ in the fluid phase during the experiment is fundamental. Conversely to the low-pressure experiments (1 bar; (Boulliung et al., 2020; Libourel et al., 2003; Miyazaki et al., 2004), the nitrogen pressure in our experiment cannot be considered during the experiment as the fraction of $\mathrm{N}_{2}$ injected in the gas mixture. 
Hence, we calculated the fluid phase $P\left(N_{2}\right)$ in our high pressure experiments by quantifying the partial pressure of the other species composing the fluid phase. In our low pressure experiments $\left(T>1200^{\circ} \mathrm{C}, \mathrm{P}<2.5 \mathrm{~kb}\right)$, we assume the ideal mixing of ideal gaseous species of $\mathrm{N}_{2}, \mathrm{H}_{2} \mathrm{O}, \mathrm{CO}_{2}, \mathrm{CO}, \mathrm{H}_{2}$ (see also lacono-Marziano et al., 2012).

The pressure of $\mathrm{H}_{2} \mathrm{O}$ and $\mathrm{CO}_{2}$ was determined after FTIR analysis (Table 4). The intensity of the IR band was converted in concentration of these elements in the silicate glass following (Shishkina et al., 2010). The calculated concentraılc? was then converted into partial pressure of $\mathrm{H}_{2} \mathrm{O}$ and $\mathrm{CO}_{2}$ using the numerical moriel 'aken from (lacono-Marziano et al., 2012). The $P(C O)$ was determined using the act..tv of $C$ (graphite) and the $\mathrm{fO}_{2}$ of the experiment using the equilibrium: $C+1 / 2$ O2 - $\mathrm{vO}$. ihe $P\left(\mathrm{~N}_{2}\right)$ was then calculated by subtracting the fugacity of the other sp=-it cited before to the "total pressure" of the experiment. The $P\left(N_{2}\right)$ was then converted in to nitrogen fugacity, $f N_{2}$, applying a 1.5 fugacity coefficient for N2 at 2.4 kbar (calcu leciei according to Belonoshko and Saxena, 1992). For the high pressure piston cylndt: experiment however, the $\mathrm{N}_{2}$-fugacity coefficient was significant $\mathrm{Y}_{\mathrm{N} 2} \approx 5,6$ (calculatec' ${ }^{2}$ cording to Belonoshko and Saxena, 1992) for $\mathrm{N}_{2}$.

\subsubsection{Secondary ion mass spectrometry (SIMS)}

The nitrogen $\left({ }^{14} \mathrm{~N}\right)$ concentration of the quenched glasses was measured by secondary ion mass spectrometry (SIMS) at the CRPG (Nancy, France), using the CAMECA 1280 HR2 ion microprobe (Füri et al., 2018). Polished glass fragments were mounted in indium and coated with a thin layer of carbon. The sample mount was stored for $48 \mathrm{~h}$ under vacuum in the airlock of the SIMS to remove any terrestrial adsorbed water before analysis. 
Spot analyses of ${ }^{14} \mathrm{~N}^{16} \mathrm{O}^{-}$secondary ions were carried out at a nominal mass resolution $\mathrm{m} / \Delta \mathrm{m}$ $=13$ '000 with a $10 \mathrm{kV} \mathrm{Cs}^{+}$primary ion beam, a current of $\sim 10 \mathrm{nA}$, and a normal-incidence electron gun to compensate the charge at the surface of the sample. Basaltic, Fe-free glasses with $\mathrm{N}$ contents between $<1$ and $3906 \pm 188$ ppm N (as determined by static mass spectrometry analysis at the CRPG noble gas facility; Humbert, 1998) were used as reference materials to calibrate the secondary ion intensity ratio ${ }^{14} \mathrm{~N}^{16} \mathrm{O}^{-} /{ }^{16} \mathrm{O}_{2}^{-}$to the nitrogen abundances of the glasses. This method has been confirmed tn $\mathrm{Vk}^{\prime} \mathrm{d} d$ nitrogen concentrations in silicate glasses of variable composition (synthesized at $\mathrm{fO}_{2}=\mathrm{IW}-8$ to $\mathrm{IW}+4.1, \mathrm{~T}=1425^{\circ} \mathrm{C}$, $P=1$ bar) that are in excellent agreement with $s^{t}$ dilc miass spectrometry measurements

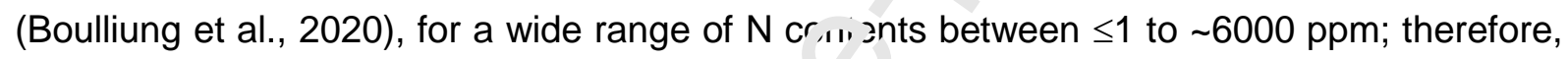
any matrix effects on the yields of $s, \mathrm{Cc}$ רa.y molecular ions $\left({ }^{14} \mathrm{~N}^{16} \mathrm{O}^{-}\right.$and $\left.{ }^{16} \mathrm{O}_{2}{ }^{-}\right)$are considered to be negligible. To ver ${ }^{\prime} \mathrm{v}$ the homogeneity of the $\mathrm{N}$ distribution, three spot analyses were performed for each qia is sample.

\section{Results}

\subsection{Description of the run products}

Most experimental products were crystal-free silicate glasses (Table 2). Only samples AR1FeN and AR1HNO3C showed a very small amount of olivine and pyroxene crystals. These crystals were observed in run number 1 , synthesised at $1200^{\circ} \mathrm{C}$, while at $1300^{\circ} \mathrm{C}$ the experimental charge was crystal-free. The presence of bubbles was noticed in all samples 
(Table 3, Fig. 1). These bubbles prove the attainment of fluid saturation during the experiment.

Another important point was the presence of droplets of metal alloy in some samples (Fig. 1), i.e., the most reduced ones and the one with added palladium powders (Table 3). These alloys were important for the $\mathrm{fO}_{2}$ calculation of the samples. In agreement with previous work (Kadik et al., 2011; Speelmanns et al., 2019), we also observed metal micronuggets in the most reduced samples (AR5SiNFeNx2; $\left.\mathrm{fO}_{2}<\mathrm{IW}-3 . \mathrm{I}\right)$. They were, however, too small to be analysed.

\subsection{Composition of the experimente.' , roducts and fluid phase}

The glass compositions of our run $p$ od cts are reported in Table 2. Most of them were synthetized using internally heated p-assure vessel experiments ('AR') and one using the piston cylinder experiment ('PCR') Ir. $r$,ost cases, the chemical compositions of the silicate glasses were similar to the $\mathrm{Ah}$ :HNO3C composition. Major compositional differences were however for the samples $\mathrm{win}_{\mathrm{h}} \mathrm{Di}_{3} \mathrm{~N}_{4}$ : those samples were enriched in $\mathrm{SiO}_{2}$ with increase from $48 \mathrm{wt} \%$ to more than $54, \mathrm{t} \%$. For these extremely reduced samples, the FeO concentration is low $(\approx 1$ wt\%) and we noticed many iron alloy nuggets (Table 3, e.g., samples AR4, AR5, PCR2). The volatile concentrations and oxygen fugacity of the different samples are reported in Table 3. In general, the samples were too $\mathrm{CO}_{2}$-poor to permit detection. Significant amounts of $\mathrm{CO}_{2}$ were only measured in samples $\mathrm{AR} 3 \mathrm{HNO}_{3} \mathrm{C}, \mathrm{AR} 4 \mathrm{NH}_{3} \mathrm{FeSClr}$, and $\mathrm{AR} 4 \mathrm{HNO}_{3} \mathrm{CPd}$ that were graphite saturated, and in which nitrogen was added in the form of an aqueous solution (Table 3). The water concentration is strongly correlated with the $\mathrm{fO}_{2}$ as 
expected from equilibrium (5). The highest $\mathrm{H}_{2} \mathrm{O}$ concentrations were measured in the samples doped in nitrogen as an aqueous solution (e.g., $\mathrm{AR} 1 \mathrm{NH}_{3}, \mathrm{AR}_{3} \mathrm{HNO}_{3} \mathrm{C}$, $\mathrm{AR} 3 \mathrm{HNO}_{3} \mathrm{AgCO}, \mathrm{AR} 4 \mathrm{NH}_{3} \mathrm{FeSCl}, \mathrm{AR}_{4} \mathrm{HNO}_{3} \mathrm{CPd}$ ). In addition to the volatile concentration of the samples, we also determined the composition of the fluid for each of them. Table 4 reports the fugacity of each component in the fluid in equilibrium with the silicate melt during the experiments. Samples with nitrogen added as an aqueous solution present the highest water and $\mathrm{CO}_{2}$ fugacities. For these samples, the fluid phase wa a multicomponent mixture, while the samples AR5SiNFeN and AR5SiNFeNx2 with a ıuirion of nitrogen as silicon nitride powders were mostly anhydrous and their fluid phas', "av essentially composed of nitrogen $\left(\mathrm{N}_{2}\right)$. The PC experiment has a fluid phase comnnsed nainly of nitrogen species. The $\mathrm{CO}_{2}$ concentration below the detection limit of he IR analysis (a few ppm) and the $\mathrm{H}_{2} \mathrm{O}$ concentration at $500 \mathrm{ppm}$ indicates that in cie fluid phase the fugacity of these elements is very low ( $<1$ bar and $\mathrm{fH}_{2} \approx 3$ bar) curpi pi ed to the total pressure (10000 bar). We therefore consider that $P($ tot $)=P\left(N_{2}\right)$ an 1 tri fugacity coefficient (see above) at $P$ and $T$ was used to calculate $\mathrm{fN}_{2}$. The uncertain ${ }_{1} ; r_{n}$ the nitrogen pressure measurement hence corresponds to the uncertainty on the pr ssure measurement of the machine $( \pm 10 \%)$.

\section{3. $\mathrm{fO}_{2}(\Delta \mathrm{IW})$ results}

For the samples with $\mathrm{fO}_{2}$ calculated using the two methods (i.e., Eqns. 7 and. 11), we compared the result to check the internal consistency and to validate the attainment of equilibrium (Table 5). In most cases, the difference between the $\log \mathrm{fO}_{2}$ values was very small and within the quoted uncertainties, i.e., between 0.1 and $0.4 \log$ units. 
The biggest variation between the two internal $\mathrm{fO}_{2}$ values was observed for the sample synthesized during run 5 , which is characterized by the lowest water content $(0.02$ and 0.04 wt\%, Table 3). For these samples, the treatment of IR spectra was difficult due to the very low intensity of the peak $(0.041 \pm 0.017$ Abs AR5SiNFeN, $0.054 \pm 0.011$ Abs PCR2SiNFeN). Nevertheless, for each sample, the differences between calculated $\mathrm{fO}_{2}$ are within or close to the propagated uncertainties.

Experiments doped in nitrogen with a mix of $\mathrm{Si}_{3} \mathrm{~N}_{4}$ and $\mathrm{Fe}_{3.5^{\prime}}$ ' seems to be the best way to produce $\mathrm{fO}_{2}$ conditions below the IW buffer (Dalou et $\left.\mathrm{a}^{\prime} ., \iota^{\prime}\right\urcorner /$ ). For the other experiments doped with other nitrogen sources such as aqueor:- sciution, the $\mathrm{fO}_{2}$ are more oxidised $\left(+1.97<\log \mathrm{fO}_{2}(\Delta \mathrm{IW})<+4.91\right)$, consistent with the nresence of large amounts of water.

When $\mathrm{fO}_{2}$ constraints from both methods if $\mathrm{Ca}^{\prime}$ ? ulations were available, we used the internal $\mathrm{fO}_{2}$ value from $\mathrm{Fe} / \mathrm{FeO}$ equilibrium in the folı ving discussion (i.e., eq. 11).

\subsection{Nitrogen concentı?tion}

Nitrogen concentrati ins it fluid saturation (Table 3) are shown in Figure 2 together with the results of previous : udies supposed to be fluid saturated at low pressure (Boulliung et al., 2020; Libourel et al., 2003; Miyazaki et al., 2004), medium pressure (Li et al., 2015) and high pressure (Grewal et al., 2019; Speelmanns et al., 2019). Nitrogen concentrations in our samples vary between 5 and $>1000 \mathrm{ppm}$. The low $\mathrm{N}$-concentration samples $(3.6 \pm 1.9$ to $26.3 \pm 5.3 \mathrm{ppm}$ ) were obtained for the most oxidizing condition $\left(\mathrm{fO}_{2}>\mathrm{IW}\right)$. In this $\mathrm{fO}_{2}$ domain, $\mathrm{N}$ content weakly varies with $\mathrm{fO}_{2}$, because nitrogen is mainly dissolved physically as $\mathrm{N}_{2}$. For the reduced samples $\left(\mathrm{fO}_{2}<\mathrm{IW}-2\right.$ ), the $\mathrm{N}$ content in the glasses increases with decreasing $\mathrm{fO}_{2}$ 
and attains, for the most reduced sample (AR5SiNFeNx2), $1737 \pm 112 \mathrm{ppm}$ at IW-4.5. These observations indicate that nitrogen concentrations are correlated with variation in $\mathrm{fO}_{2}$ only for conditions below IW-1.5: under these conditions, if the $\mathrm{fO}_{2}$ continue to decrease, the nitrogen concentration increases drastically.

\section{Discussion}

\subsection{Attainment of equilibrium}

To demonstrate that the equilibrium of our experi' 1 . 'ts was reached, the homogeneity of our samples was verified using different methor= Firstly, we check the homogeneity of the major elements through the chemical cor. $\sim$ 'sı.?n of our silicate glass $\left(\mathrm{SiO}_{2}, \mathrm{Al}_{2} \mathrm{O}_{3}, \ldots\right)$, if the glass shows good homogeneity, this indicates that the latter was in equilibrium. The second important point to verify is the homoy n n:ty of the nitrogen concentration within the sample in order to see if the nitrogen $h$ d suificient time to diffuse in the sample in a homogeneous way. The third point is the $n_{1}$, urgence of the internal $\mathrm{fO}_{2}$ value read with the two techniques explained in section 3.?. Only if these three elements are verified we validate the achievement of equilibrium during the experiment. In addition, a comparison with the equilibrium data taken in the literature is carried out to check consistency.

For our study, by referring to the different tables (Table $2,3,5$ ) we can verify this attainment of equilibrium for all samples. The chemical composition $\left(\mathrm{SiO}_{2}, \mathrm{FeO}, \ldots\right)$ of the different sample shows a good spatial homogeneity, with minor compositional variation between the different analysis points (Cf. Table 2.). This observation can also be made for the 
concentrations of volatile elements including nitrogen, the concentration only weakly varies between the different analysis points (Cf. Table 3.). Regarding to the internal $\mathrm{fO}_{2}$ values obtain by the two different calculation ways, i.e. water activity and $\mathrm{Fe} / \mathrm{FeO}$ activities, the equilibrium seems to be reach due to the similar results of these two techniques (Cf. Table 5.). Lastly when we compare our point with those of previous studies, we notice that our points are part of a logical trend of those already obtained by previous studies. Our nitrogen concentration evolves in a way similar to that of Liboures ot al. (2003), with higher concentrations, linked to pressure and therefore nitroger ius acity differences (i.e. 1 atm vs 800 bar). Our high-pressure anchor point (Cf. Figure _. h/ц concentration ranges observed by other high-nressure studies (i.e. Grewal et al., 2019; Speelmanns et al., 2019).

\subsection{Nitrogen species ar. 1 s z.ubility as a function of $\mathrm{fO}_{2}$ and pressure}

Figure 2 shows that prossu'e has a major effect on the nitrogen solubility for all investigated conditions if 0 ) ygen fugacities. For $\mathrm{fO}_{2}>\Delta \mathrm{IW}$, no $\mathrm{fO}_{2}$-dependency is observed with similar trends obisived at low pressure (1 bar; Libourel et al., 2003) and in our experiments performed at medium pressures (i.e., 0.8 and 2.4 kbar). However, our data are shifted by two to three log-units upward in term of nitrogen concentration. $A t \mathrm{fO}_{2}>\mathrm{IW}$, our results show similar $\mathrm{N}$-concentrations than those reported in previous study ( $\mathrm{Li}$ et al., 2015, $\sim 10 \mathrm{ppm}$ ), thus confirming the lack of $\mathrm{fO}_{2}$ dependence. There is therefore a significant effect of pressure and independently of the nitrogen fugacity; with a general increase of one log unit in $\mathrm{N}$-content as pressure increases by one order of magnitude. A similar trend can be 
observed in experiments performed at higher pressures (Grewal et al., 2019; Speelmanns et al., 2019), with a comparable increase of $\mathrm{N}$ concentration at higher pressures (Fig. 2). Fig. 2 also shows the duality of $\mathrm{N}$-solubility behaviour, reflecting most likely (i) a physical, $\mathrm{fO}_{2}$ independent, $\mathrm{N}_{2}$ dissolution under oxidising conditions (> IW-1.5) and (ii) a chemical dissolution of $\mathrm{N}^{3-}$ that is strongly enhanced at the most reduced conditions. The hypothesis of a dual N-speciation, described first by (Libourel et al., 2003) at atmospheric pressure, seems to be confirmed at medium pressure within our experimental daia.

\subsection{Calibration of the solubility model}

We have compiled a database containing n'،rc gen concentrations in melts of different experimental studies at different pressı res temperatures and $\mathrm{fO}_{2}$ conditions. We only use the data of nitrogen concentration in bai altic melts that we assume to be equilibrated at fluid saturation (an assumption tha' 'nud be verified for studies containing the relevant information). In addition to $o^{r} \epsilon$, periments, the database contains data from low pressure

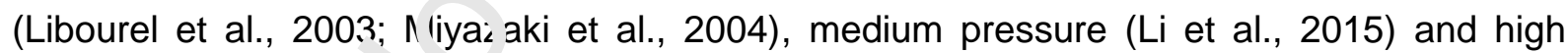
pressure experiments :-1.5 GPa; Grewal et al., 2019; Speelmanns et al., 2019). The parameters of the database were: nitrogen contents in the melt, temperature $\left({ }^{\circ} \mathrm{C}, \mathrm{K}\right)$, pressure (bar), oxygen fugacity $\left(\mathrm{fO}_{2}, \log \mathrm{fO}_{2}, \log \mathrm{fO}_{2}(\Delta \mathrm{IW})\right.$ and the nitrogen fugacity $\left(\mathrm{fN}_{2}\right)$. We restricted the database to studies with similar starting material ( $\approx$ basalt), in order to reduce the potential effect of the NBO/T on the nitrogen solubility (Mysen et al., 2008; Roskosz et al., 2006; Boulliung et al., 2020). We have also dismissed some studies that investigated nitrogen metal-silicate partitioning because they have no proof of fluid in the 
synthesized samples (such as bubbles trapped in the glass e.g Dalou et al., 2019b, 2017). Using this database, we can represent the effect of nitrogen pressure on nitrogen solubility (Fig. 3). The nitrogen concentration data used for figure 3 are for conditions more oxidizing than IW-2 in order to restrict the effect of $\mathrm{fO}_{2}$. In agreement with previous observations (Roskosz et al., 2006), the nitrogen concentration appears to increase as the pressure, and therefore the nitrogen fugacity increases. This observation is valid for reduced and oxidized conditions and suggests that $\mathrm{N}_{2}$ remains the dominant $\mathrm{N}$-specins in the fluid for all these experimental studies. According to Chen et al. (2019), + it $V_{2}$ species fraction in the fluid increases with $\mathrm{fO}_{2}$. In addition, an increase of the : $: \eta_{1}$ erature and/or the total nitrogen concentration in the fluid phase appears to increace the $\mathbb{N}_{2}$ fraction in the fluid at the expense of $\mathrm{NH}_{3}$. In contrast, a pressure rise will in artise the $\mathrm{NH}_{3}$ fraction in the fluid (Chen et al., 2019). When we extrapolate the result o Chen et al. (2019) to the conditions of the experimental data in Figure 3, the m. $\mathrm{a}^{\mathrm{i}} \mathrm{1}$ : pecies present in the fluid tends to be $\mathrm{N}_{2}$.

The two dissolution reactions "sea 'or the N-solubility model are:

$$
\begin{gathered}
N_{2(\text { gas })}=N_{2(\text { silicate melt })} \\
\frac{1}{2} N_{2(\text { gas })}+\frac{3}{2} O_{(\text {silicate melt })}^{2-}=N_{(\text {silicate melt })}^{3-}+\frac{3}{4} O_{2(\text { gas })}
\end{gathered}
$$

Reaction 13 corresponds to the physical dissolution of $\mathrm{N}_{2}$, whereas reaction 14 corresponds to the chemical dissolution of $\mathrm{N}^{3-}$. The total nitrogen concentration in the silicate melt corresponds to the sum of the two species concentration. 


$$
\left[N_{\text {calc }}\right]=\left[N_{2}\right]+\left[N^{3-}\right]
$$

From the eq. 13 , we can calculate the $\mathrm{N}_{2}$ concentration, which mainly depends on nitrogen fugacity:

$$
\left[N_{2}\right]=K_{13} * f N_{2}
$$

From the eq. 14, we can calculate the $\mathrm{N}^{3-}$ concentration, wr icı, mainly depends on $\mathrm{fO}_{2}$ and $\mathrm{fN}_{2}:$

$$
\left[N^{3-}\right]=f O_{2}^{-3 / 4} * K_{14} *{ }^{C} N_{2}{ }^{\prime 2}
$$

The eq. 16 and 17 once replaced in eq. $1^{5} \neg \|$ "/s us to propose the nitrogen concentration in silicate melt as:

$$
\left[N_{\text {calc }}\right]=K_{13} \cdots+f O_{2}{ }^{-3 / 4} * K_{14} * f N_{2}{ }^{1 / 2}
$$

The thermodynamic constants $\left., K_{13}, K_{14}\right)$ of the two reactions follow this form

$$
K=\exp \left(\frac{-\Delta r G^{P, T}}{R T}\right)
$$

where

$$
\Delta r G^{P, T}=\Delta r H-T \Delta r S+P \Delta r V
$$

$\mathrm{P}$ and $\mathrm{T}$ correspond to the pressure (bar) and temperature $(\mathrm{K})$ of the system. In the eq. 20, $\Delta \mathrm{rG}^{\mathrm{P}, \mathrm{T}}$ corresponds to the Gibbs free energy of the reaction for given and variable $\mathrm{P}$ and $\mathrm{T}$ 
values, calculated with, $\Delta \mathrm{rH}$ the enthalpy, $\Delta \mathrm{rS}$ the entropy and $\Delta \mathrm{rV}$ the volume of the reaction at $P$ and $T$. All the thermodynamic constants were adjusted using the low, medium and highpressure data and the result is given in Table 6.

We assumed that the enthalpy and entropy are constant over the $T$ range, although this assumption was not applied to the volume changes of reaction (13) and (14). The following correction was applied in the P-range 0-1 GPa:

$$
\Delta V=\Delta \mathrm{V}+P \Delta V^{\prime}
$$

At $\mathrm{P}>1 \mathrm{GPa}$, the volume changes are considered constan .

The constants $\Delta \mathrm{H}_{13}, \Delta \mathrm{S}_{13}$ and $\Delta \mathrm{V}_{13}$ were used for th $\doteq \mathrm{Cc}^{\prime}$ 'culation of the $\mathrm{K}_{13}$ and characterise the physical dissolution of $\mathrm{N}_{2}$ in the silicate $\mathrm{m}_{\mathrm{G}}$. $\Delta \mathrm{H}_{14}, \Delta \mathrm{S}_{14}$ and $\Delta \mathrm{V}_{14}$ were used for the calculation of $\mathrm{K}_{14}$ and therefore characte $\mathrm{ISt}_{\mathrm{St}}$ the chemical dissolution of $\mathrm{N}^{3-}$. These two sets

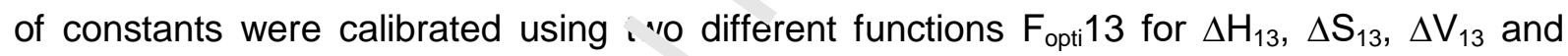
$\mathrm{F}_{\text {opti }} 14$ for $\Delta \mathrm{H}_{14}, \Delta \mathrm{S}_{14}, \Delta \mathrm{V}_{14}$ of the form

$$
\begin{gathered}
I_{\iota \cdot t i} 13=\sum \frac{\left|N_{\text {mes }}-N_{\text {calc }}\right|^{2}}{\sigma_{N_{\text {mes }}}} \\
F_{\text {opti }} 14=\sum \frac{\left|N_{\text {mes }}-N_{\text {calc }}\right|^{2}}{\sigma_{N_{\text {mes }}}}+\frac{\left|f O_{2 \text { mes }}-f O_{2 \text { calc }}\right|^{2}}{\sigma_{N_{\text {mes }}}} * 0.01
\end{gathered}
$$

$\mathrm{F}_{\mathrm{opti}} 13$ was used to minimize the difference between the measured and the calculated $\mathrm{N}$ concentration for the most oxidised data (>IW-1.5). $F_{\text {opti }} 14$ was used to minimize the difference in term of nitrogen concentration and oxygen fugacity for the most reduce data 
(<IW-1.5). This formalism allowed us to produce a model taking into account both uncertainties in $\mathrm{N}$ content and $\mathrm{fO}_{2}$.

The error estimation for the 6 constants presented in the Table 6 is calculated for an increase in the residue on the fitting function presented above of $30 \%$. This threshold allows us to determine the range of variation (maximum and minimum values) for each of our constants. This $30 \%$ threshold is comparable to the average value of the uncertainty in the measurement of nitrogen contents in glasses (31\%) in the complid database.

Results obtained experimentally and calculated by the $r$ ı $\iota^{\prime} \geqslant \mid$ were then compared in two different ways. First, we compare the calculated date $i=t_{1}, 3$ analysed nitrogen concentration in the silicate melt as a function of $\mathrm{fO}_{2}(\Delta \mathrm{IW}$; Fig. $\Delta)$.

The results of the model are in good ־ ־re ment with experimental data (Fig. 4). If we compare the calculated nitrogen concentrai.jn to the measured data (Fig. 4), we obtain a data array aligned along a straight 'ire uf slope $1(R 2=0.96)$. These observations support the accuracy of the calculated ilata.

In details, we see that the su' ''jility model captures well the trend. However, for some data points, the differences $\mathrm{w}$ tween the calculated and measured data exceed the uncertainties which is likely due to some uncertainties in the composition of the fluid phase of the experiments used for the calibration.

The 2-species model first presented by Libourel et al. (2003) at a pressure of 1 bar is validated here to moderately high pressure in a $\mathrm{C}-\mathrm{H}-\mathrm{O}-\mathrm{N}$ system. The temperature range covered by the database is from 1100 to $2000^{\circ} \mathrm{C}$, the pressure from 1 bar to 10000 bar and the $\mathrm{fO}_{2}$ from IW-8 to IW+8. The chemical composition is mainly basaltic. The volume 
changes of the two dissolution mechanisms are respectively positive and negative, which is consistent with fact that the volume change of reaction (13) is the partial molar volume of $\mathrm{N}_{2}$ (being positive), while the volume change of reaction (14) is the difference between the volume of $\mathrm{N}^{3-}$ and $3 / 2$ the volume of $\mathrm{O}^{2-}$ (being negative). In detail, we notice that the fitted partial molar volume of $\mathrm{N}_{2}$ in the silicate melt is close to the partial molar volume of $\mathrm{N}_{2}$ liquid at $1 \mathrm{~atm}$. and its boiling point (i.e., $34.5 \mathrm{cc} / \mathrm{mol} .=3.5 \mathrm{~J} / \mathrm{bar}$ ). Although the fluid phase of the model was assumed to be $\mathrm{N}_{2}$-dominated (it does not take into a'sount the presence of $\mathrm{NH}_{3}$ in the fluid phase), our model also adequately describes un IV-solubility at low pressure to moderately high-pressure. A more complicated $\mathrm{mr}$, 'n : cluding $\mathrm{NH}_{3}$ in the fluid is not required at this stage, probably due to the fart inat host experiments performed under reduced conditions are generally dry (Tahl $=5$, implying low $\mathrm{fH}_{2}$ conditions. Since the $\mathrm{NH}_{3} / \mathrm{N}_{2}$ speciation is ruled by the respective equilibrı:

$$
\mathrm{N}_{2}+\mathrm{J}_{3} \mathrm{C}=2 \mathrm{NH}_{3}+3 / 2 \mathrm{O}_{2}
$$

or

$$
\mathrm{N}_{2}+3 \mathrm{H}_{2}=2 \mathrm{NH}_{3}
$$

it clearly appears that low $\mathrm{fH}_{2}$ (and low $\mathrm{fH}_{2} \mathrm{O}$ ) strongly reduces the presence of $\mathrm{NH}_{3} . \mathrm{NH}_{3}$ is also precluded by the high $\mathrm{N}$-content of our fluid phase, the high temperature and the moderately high-pressure condition, in agreement with previous observations (Chen et al., 2019).

A second working hypothesis concerns the nitrogen species in the silicate melt. We considered two main species: $\mathrm{N}_{2}$ and $\mathrm{N}^{3-}$. Several previous studies (Dalou et al., 2019b; 
Grewal et al., 2020; Kadik et al., 2015; Mosenfelder et al., 2019) suggested the presence of $\mathrm{NH}_{x}$ species where $\mathrm{N}$ has the valence of $\mathrm{N}^{3-}$. Here, a two-species model $\left(\mathrm{N}_{2}\right.$ and $\left.\mathrm{N}^{3-}\right)$ adequately describes the $\mathrm{fO}_{2}-\mathrm{P}-\mathrm{T}$ dependence of $\mathrm{N}$-solubility. No attempt to parameterize an $\mathrm{NBO} / \mathrm{T}$ parameter was considered though a significant effect of NBO/T on N-solubility was previously underlined (Mysen and Fogel, 2010; Boulliung et al., 2020). Here, this parameter has not been considered because in agreement with the observations of the articles Boulliung et al. (2020), for the $\mathrm{fO}_{2}$ conditions of most of the poink used by the database (i.e. $>$ IW $-5,1)$, the NBO / T has an impact that is still difficult $\iota$ rerıne and requires more work. For the time being, this model is accurate for descr;' : ' 9 the available database. However, this model will have to consider other melt and flı in specıs once their P-T-fO ${ }_{2}$ domain will be better defined. In particular, data at low ${ }^{\wedge} \mathrm{sc}$. tent or at least at low N/H and low N/C are needed.

\subsection{Model applicatian in melt degassing processes}

Eq. 18 permits the preuivtion of nitrogen solubility in a basaltic melt in the $\mathrm{P}-\mathrm{fO}_{2}$ parameter space. For a constant temperature of $1200^{\circ} \mathrm{C}$, we can make a series of isobars of nitrogen fugacity on a diagram nitrogen concentration as a function of $\mathrm{fO}_{2}$ (Fig. 6). Fig. 6 shows that both $\mathrm{N}_{2}$ and $\mathrm{N}^{3-}$ species have solubilities that increase with increasing nitrogen pressure. In details, the $\mathrm{fO}_{2}$ at which speciation changes from $\mathrm{N}_{2}$ to $\mathrm{N}^{3-}$ decreases as pressure increases. At low pressure, the $\mathrm{N}_{2}-\mathrm{N}^{3-}$ transition occurs at IW, while at $3 \mathrm{GPa}$, it occurs at IW-3. There is therefore a shift of 1 - $\log$ unit in $\mathrm{fO}_{2}$ per $\mathrm{GPa}$ of the boundary separating the $\mathrm{N}_{2}$ dominated 
from the $\mathrm{N}^{3-}$ dominated area. This shift can be explained by the dependence on $\mathrm{P}\left(\mathrm{N}_{2}\right)$ of the solubility of both $\mathrm{N}_{2}$ and $\mathrm{N}^{3-}$ species (Eqns. $16 \& 17$ ). $\mathrm{N}_{2}$ dissolution mechanism has $a+1$ exponent on $\mathrm{P}\left(\mathrm{N}_{2}\right)$ while $\mathrm{N}^{3-}$ dissolution mechanism has a 0.5 exponent dependence on $P\left(N_{2}\right)$. This implies that the $f_{2}$ domain where the $\mathrm{N}$-speciation shifts from $\mathrm{N}_{2}$ to $\mathrm{N}^{3-}$ must change with $P\left(N_{2}\right)$ rather than total pressure.

Degassing of Earth's magma ocean is supposed to have occurred at $\mathrm{fO}_{2}$ conditions ranging from IW-5, at the beginning of the magma ocean stage, to IW- 2 in the lastest stages (Wood et al., 2006). This is deduced from metal partitioning '،urı'g core - mantle equilibration processes, but admittedly, after the core segregatior, $\mathrm{I}_{1} ?$ Inagma ocean could have evolved more oxidized. At IW-5 and fluid saturation, th' sitrogen content in the silicate melt is ca. $3000 \mathrm{ppm}(0.3 \mathrm{wt} \%)$ for $\mathrm{fN}_{2}$ of 100 bar ( 5 t Fly 6). At IW-2, corresponding to the last stage of magma ocean-core equilibration, : he nitrogen content in the silicate melt for a similar $\mathrm{fN}_{2}$ decreases and attains $10 \mathrm{ppm}(0 . \mathrm{Cl} \mathrm{Nt} \%)$. This implies a drastic change of the nitrogen behaviour during this period if coie mantle segregation. According to Speelmanns et al. (2018), nitrogen became :rrusingly siderophile during the last stage of the core-magma ocean segregation (i.e., is the oxygen fugacity evolved from $\Delta \mathrm{IW}-5$ to IW-2). However, as the magma ocean went through this redox interval (from $\Delta \mathrm{IW}-5$ to $\Delta \mathrm{IW}-2$ ), nitrogen became also more atmophile as shown by Figure 6 . This is because the oxidation state of $\mathrm{N}$ in metal and the gas phases is similar (zero). These two phenomena, $\mathrm{N}$ incorporation in metal vs. $\mathrm{N}$ degassing, thus entered in competition at the end of the core mantle equilibration at ca. IW-2. This made more difficult the incorporation of $\mathrm{N}$ in the core. In summary, at very low $\mathrm{fO}_{2}, \mathrm{~N}$ is neither siderophile nor atmophile, it is magmatophile, while at intermediate $\mathrm{fO}_{2}(\mathrm{IW}-2), \mathrm{N}$ is 
siderophile and atmophile. We note that planetary systems experiencing very low $\mathrm{fO}_{2}$ (ie. IW5) during their magma ocean and post-magma ocean stages, such as Mercury, may accordingly contains high nitrogen content in their mantle. In contrast, planets like Earth and Mars, that experienced core-magma ocean equilibration close to IW-2, must have little $\mathrm{N}$ contents in their mantle.

\subsection{Nitrogen impact on the volcanism of planets vith reduced magmatic} conditions

As explained above, under reduced conditions itru en is magmatophile (not siderophile, nor atmophile), implying that reduced magm 1 or eans must crystallize under high $\mathrm{N}$-activity while oxidized magma oceans would solidı; under low $\mathrm{N}$-activity. No melt-crystal N-partitioning experiments exist. However, som_ si.jies, which focus on the nitrogen solubility in mantle minerals (Li et al., 2013; Yc-hı'ka et al., 2018), compare their solubility results for mantle minerals with data of ni rog $n$ solubility in silicate melt of previous studies (Libourel et al., 2003; Miyazaki et al., =J04; Roskosz et al., 2013). From these comparisons, the two minerals studies deduce mineral-melt nitrogen partitioning, one of the important criteria for discussing nitrogen degassing.

Since nitrogen can be incorporated into mantle minerals (Li et al., 2013; Yoshioka et al., 2018), we may assume that a solidifying magma ocean can sequester nitrogen in its mantle. In turn, assuming that $\mathrm{N}$ is incompatible upon partial melting (which is likely at $\mathrm{fO}_{2}$ $<\mathrm{IW}-3)$, it can be incorporated into the liquid and transported to the surface. High N-content 
in the melt may impact the degassing process during the magma ascent and, in fine, the eruption. However, such features are not relevant for the current volcanism on Earth or Mars due to oxidising condition ( $\approx \mathrm{IW}$ to $\mathrm{FMQ;} \mathrm{Righter} \mathrm{et} \mathrm{al.,} \mathrm{2008)} \mathrm{yielding} \mathrm{low} \mathrm{nitrogen}$ concentrations in their cooling magma oceans. For a planet with strongly reduced conditions like Mercury, where the $\mathrm{fO}_{2}$ of its interior was estimated to be between $\Delta \mathrm{IW}-6.3$ to -2.6 (McCubbin et al., 2012) or $\Delta \mathrm{IW}-7.3$ to -4.5 (Zolotov et al., 2013), nitrogen can be highly concentrated in the silicate melt with contents exceeding $\left.1000 \mu_{1}\right\urcorner \mathrm{m}$. In addition, the low $\mathrm{fO}_{2}$ conditions of Mercury do not allow the stability of species sun h as $\mathrm{H}_{2} \mathrm{O}$ or $\mathrm{CO}_{2}$ but favour the stability of volatile species such as $\mathrm{S}_{2}, \mathrm{CO}$ and $\mathrm{CH}_{\mathrm{X}}^{2}$, irkreasing the $\mathrm{H}_{2} / \mathrm{H}_{2} \mathrm{O}$ and $\mathrm{C} / \mathrm{O}$ ratio (Cartier and Wood, 2019; Ebel and Alexander, 2ni1; Zuiotov, 2011). According to our data and previous formalism for reduced condit: $n_{i}$ (i.e., IW<-6, Zolotov, 2011) several wt\% of $N$ are lost by a pressure drop of $1 \mathrm{kbar}$ (red al, Jw fig. 6). It is therefore likely that, under these conditions, nitrogen was one of th $3 m_{x}$ in volatile species, which can impact the eruptive dynamics on Mercury similarly o witer for Earth. 


\section{Conclusion}

This new experimental study provides constraints on the solubility of nitrogen in basaltic melts at fluid-saturation under lithospheric pressure. It indicates that for the most oxidised conditions, nitrogen solubility is low and depends mainly on the nitrogen pressure $\left(\mathrm{N}_{2}\right.$ dissolution). For the most reduced conditions $(<\mathrm{IW})$, nitrogen solubility increases drastically and is correlated to the decrease in $\mathrm{fO}_{2}\left(\mathrm{~N}^{3-}\right.$ dissolution). Tr es€ observations corroborate a previous studies at low pressure (Libourel et al., 2003; Гo."lii.ng et al., 2020). A two species solubility model $\left(\mathrm{N}_{2}, \mathrm{~N}^{3-}\right)$ of nitrogen in silicate melt w. s $\mathrm{c}$ dibrated with our data and previous data for fluid saturated conditions (Grewal et a .2(19; Li et al., 2015; Libourel et al., 2003; Miyazaki et al., 2004; Speelmanns et al 25 19). This model successfully reproduces most of the literature data at fluid saturation. hu'vever, we assumed some starting hypothesis (4.2.) that need to be verified aga'is: a larger set of experimental work. These results (experimental and modelled) $: m_{\uparrow}$ hasize that nitrogen degassing from a magma ocean must predominantly occur in $\mathrm{t}$ e $\mathrm{f(})_{2}$ range IW-9 to IW. Pressure is also an important parameter. A

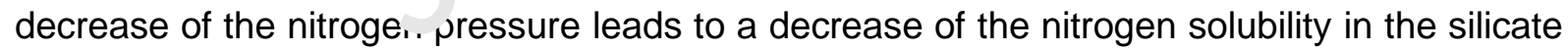
melt (see eq. 17), thus contributing to degassing. On reduced planets like Mercury, nitrogen can be a trigger for explosive eruptions.

The solubility model must evolve in the future with new data at low nitrogen activity in order to test the presence of $\mathrm{NH}_{3}$ in both melt and fluid phases. More data at high pressure and fluid saturation are also needed. 
Nitrogen partitioning between the metal and the silicate melt is an additional important process to take into account. In most of the recent studies of the partitioning of nitrogen between silicate melt and liquid iron-alloy, nitrogen appears to be more siderophile when the condition become more oxidised (Dalou et al., 2019b; Speelmanns et al., 2019, 2018) and more lithophile at reduced conditions. We note a similar behaviour between silicate melt and fluid phase: when the condition becomes more oxidised, nitrogen becomes more atmophile. Future efforts must consider this complex three-phase issut. chemical exchange of $\mathrm{N}$ between the metal, the silicate melt and the gas phases.

\section{Acknowledgements}

This work is part of the $\mathrm{PhD}$ of Fabien B-rnauvu being supported by the university of Orleans. The authors acknowledge the LASTON project (ANR-18-CE31-0021). Chemical analyses at ISTO and CRPG were sa $\imath^{\prime \prime}$ supported by the PLANEX investissement d'avenir project (ANR-11-EQPX-36). W? '’’ank Cécile Deligny and Johan Villeneuve (CRPG, Nancy) for providing help during S'MS analysis. David Sifré is thanked for his help on the piston cylinder experiment. $v^{\prime}$ ? aiso thank Patricia Benoist (SEM, ISTO), Ida Di Carlo (EPMA, ISTO), Marielle Hatton (Elemental analyser, ISTO) and Emmanuel Véron (XRD, Cemhti) for the help with analysis. We would like to thank the anonymous reviewer for these comments and corrections.

\section{References}


Aukrust, E., Muan, A., 1962. Thermodynamic properties of Pd-Fe alloys in the Temperature range $1200-1460^{\circ} \mathrm{C}$. Acta Metall. 10, 555-560.

Belonoshko, A.B., Saxena, S.K., 1992. A unified equation of state for fluids of C-H-O-N-S-Ar composition and their mixtures up to very high temperatures and pressures. Geochim. Cosmochim. Acta 56, 3611-3626. https://doi.org/10.1016/0016-7037(92)90157-E

Boulliung, J., Furï, E., Dalou, C., Tissandier, L., Zimmermann, L., Marrocchi, Y., 2020. Oxygen fugacity and melt composition controls on nitrogen solubility in silicate melts. Geochim. Cosmochim. Acta.

Cartier, C., Wood, B.J., 2019. The Role of Reducing Conditions in Building Mercury. Elements 15, 3945. https://doi.org/10.2138/gselements.15.1.39

Catling, D.C., Zahnle, K.J., 2020. The Archean atmosphere. Sci. Adv. 6, eaax1420. https://doi.org/10.1126/sciadv.aax1420

Chen, Q., Zhang, Z., Wang, Z., Li, W.-C., Gao, X.-Y., Ni, H., 2019. In situ Raman spectroscopic study of nitrogen speciation in aqueous fluids under pressure. Chem Geol. 506, 51-57. https://doi.org/10.1016/j.chemgeo.2018.12.016

Dalou, C., Füri, E., Deligny, C., Piani, L., Caumon, M.-C., Laumonier, M., Zoulliung, J., Edén, M., 2019a. Redox control on nitrogen isotope fractionation during $\mathrm{nlar}^{-+}$.ry core formation. Proc. Natl. Acad. Sci. 116, 14485-14494. https://doi.org/10.1073/. nas 1820719116

Dalou, C., Hirschmann, M.M., Jacobsen, S.D., Le Losq, C., 201' 'b. kaman spectroscopy study of C-O-H$\mathrm{N}$ speciation in reduced basaltic glasses: Implicati $11 \mathrm{~s}^{\circ} \mathrm{ol}$ reduced planetary mantles. Geochim. Cosmochim. Acta 265, 32-47. https://a : or s/10.1016/j.gca.2019.08.029

Dalou, C., Hirschmann, M.M., von der Handt, A., Mosenf _Ider, '.., Armstrong, L.S., 2017. Nitrogen and carbon fractionation during core-mantle dif erei tiation at shallow depth. Earth Planet. Sci. Lett. 458, 141-151. https://doi.org/10.10i6/J. - nsl.2016.10.026

Ebel, D.S., Alexander, C.M.O., 2011. Equilibri' $m$ onci znsation from chondritic porous IDP enriched vapor: Implications for Mercury and $~ n$, tatite chondrite origins. Planet. Space Sci. 59, 18881894. https://doi.org/10.1016/j. nss.2011.07.017

Füri, E., Deloule, E., Dalou, C., 2018. Nitrogt. abundance and isotope analysis of silicate glasses by secondary ionization mass sper crs, -try. Chem. Geol. 493, 327-337. https://doi.org/10.1016/j.ch_..ng - $=2018.06 .008$

Gaillard, F., Schmidt, B., Mackwell - Mciammon, C., 2003. Rate of hydrogen-iron redox exchange in silicate melts and glass - Geochim. Cosmochim. Acta 67, 2427-2441. https://doi.org/10.1016/ ר16-7037(02)01407-2

Gennaro, E., lacono-Marziann. C 'aonita, A., Rotolo, S.G., Martel, C., Rizzo, A.L., Pichavant, M., Liotta, M., 2019. $N$ elt it clusions track melt evolution and degassing of Etnean magmas in the last 15 ka. Lithos : ?4-s25, 716-732. https://doi.org/10.1016/j.lithos.2018.11.023

Grewal, D.S., Dasgupta, R . F arnell, A., 2020. The speciation of carbon, nitrogen, and water in magma oceans and its effect on volatile partitioning between major reservoirs of the Solar System rocky bodies. Geochim. Cosmochim. Acta 280, 281-301. https://doi.org/10.1016/j.gca.2020.04.023

Grewal, D.S., Dasgupta, R., Holmes, A.K., Costin, G., Li, Y., Tsuno, K., 2019. The fate of nitrogen during core-mantle separation on Earth. Geochim. Cosmochim. Acta 251, 87-115. https://doi.org/10.1016/j.gca.2019.02.009

Humber F. (1998) Solubilité de l'azote dans les silicates liquides influence de la fugacité d'oxygène et de la composition, Ph. D. thesis. Henri Poincaré- Nancy 1 University.

Iacono-Marziano, G., Morizet, Y., Le Trong, E., Gaillard, F., 2012. New experimental data and semiempirical parameterization of $\mathrm{H} 2 \mathrm{O}-\mathrm{CO} 2$ solubility in mafic melts. Geochim. Cosmochim. Acta 97, 1-23. https://doi.org/10.1016/j.gca.2012.08.035

Kadik, A.A., Koltashev, V.V., Kryukova, E.B., Plotnichenko, V.G., Tsekhonya, T.I., Kononkova, N.N., 2015. Solubility of nitrogen, carbon, and hydrogen in FeO-Na2O-Al2O3-SiO2 melt and liquid iron alloy: Influence of oxygen fugacity. Geochem. Int. 53, 849-868.

https://doi.org/10.1134/S001670291510002X 
Kadik, A.A., Kurovskaya, N.A., Ignat'ev, Yu.A., Kononkova, N.N., Koltashev, V.V., Plotnichenko, V.G., 2011. Influence of oxygen fugacity on the solubility of nitrogen, carbon, and hydrogen in $\mathrm{FeO}-\mathrm{Na2O}-\mathrm{SiO} 2-\mathrm{Al} 2 \mathrm{O} 3$ melts in equilibrium with metallic iron at $1.5 \mathrm{GPa}$ and $1400^{\circ} \mathrm{C}$. Geochem. Int. 49, 429-438. https://doi.org/10.1134/\$001670291105003X

Li, Y., Huang, R., Wiedenbeck, M., Keppler, H., 2015. Nitrogen distribution between aqueous fluids and silicate melts. Earth Planet. Sci. Lett. 411, 218-228. https://doi.org/10.1016/j.epsl.2014.11.050

Li, Y., Keppler, H., 2014. Nitrogen speciation in mantle and crustal fluids. Geochim. Cosmochim. Acta 129, 13-32. https://doi.org/10.1016/j.gca.2013.12.031

Li, Y., Wiedenbeck, M., Shcheka, S., Keppler, H., 2013. Nitrogen solubility in upper mantle minerals. Earth Planet. Sci. Lett. 377-378, 311-323. https://doi.org/10.1016/j.epsl.2013.07.013

Libourel, G., Marty, B., Humbert, F., 2003. Nitrogen solubility in basaltic melt. Part I. Effect of oxygen fugacity. Geochim. Cosmochim. Acta 67, 4123-4135. https://doi.org/10.1016/S00167037(03)00259-X

Marty, B., 2012. The origins and concentrations of water, carbon, nitic $c_{c}^{-a n}$ and noble gases on Earth. Earth Planet. Sci. Lett. 313-314, 56-66. https://doi.org/10 101 -/j.epsl.2011.10.040

Marty, B., Zimmermann, L., Pujol, M., Burgess, R., Philippot, P., 2n1_ 'ittrogen Isotopic Composition and Density of the Archean Atmosphere. Science 342, . 01- 04. https://doi.org/10.1126/science.1240971

McCubbin, F.M., Riner, M.A., Vander Kaaden, K.E., Burker.pe: L.K., 2012. Is Mercury a volatile-rich planet?: VOLATILES ON MERCURY. Geophys. Res. . गtt 39, n/a-n/a. https://doi.org/10.1029/2012GL051711

Medard, E., McCammon, C.A., Barr, J.A., Grove, T.L., 2 J J?. Oxygen fugacity, temperature reproducibility, and $\mathrm{H} 2 \mathrm{O}$ contents of nom i nalı anhydrous piston-cylinder experiments using graphite capsules. Am. Mineral. 93, 1 63 ، -1 $10^{1} 4$. https://doi.org/10.2138/am.2008.2842

Miller, S.L., 1953. A Production of Amino Acli-' 'Jnder Possible Primitive Earth Conditions. Science 117, 528-529. https://doi.org/1n.1126/science.117.3046.528

Miyazaki, A., Hiyagon, H., Sugiura, N., Hirosc, K., Takahashi, E., 2004. Solubilities of nitrogen and noble gases in silicate melts un te $\checkmark$-ious oxygen fugacities: implications for the origin and degassing history of nitroger - na - . Jble gases in the earth. Geochim. Cosmochim. Acta 68, 387-401. https://doi.org/1i 1010/S0016-7037(03)00484-8

Mosenfelder, J.L., Von Der Handt, 1., Furi, E., Dalou, C., Hervig, R.L., Rossman, G.R., Hirschmann, M.M., 2019. Nitrogen inc rporation in silicates and metals: Results from SIMS, EPMA, FTIR, and laser-extraction ma.c pectrometry. Am. Mineral. 104, 31-46. https://doi.org/10 ?13i/am-2019-6533

Mysen, B.O., Fogel, M.L., ' ' Iu. Nitrogen and hydrogen isotope compositions and solubility in silicate melts in equilibriı 1 with reduced $(\mathrm{N}+\mathrm{H})$-bearing fluids at high pressure and temperature: Effects of melt structure. Am. Mineral. 95, 987-999. https://doi.org/10.2138/am.2010.3364

Mysen, B.O., Yamashita, S., Chertkova, N., 2008. Amorphous materials: Properties, structure, and durability: Solubility and solution mechanisms of $\mathrm{NOH}$ volatiles in silicate melts at high pressure and temperature--amine groups and hydrogen fugacity. Am. Mineral. 93, 17601770. https://doi.org/10.2138/am.2008.2879

Righter, K., Yang, H., Costin, G., Downs, R.T., 2008. Oxygen fugacity in the Martian mantle controlled by carbon: New constraints from the nakhlite MIL 03346. Meteorit. Planet. Sci. 43, 17091723. https://doi.org/10.1111/j.1945-5100.2008.tb00638.x

Roskosz, M., Bouhifd, M.A., Jephcoat, A.P., Marty, B., Mysen, B.O., 2013. Nitrogen solubility in molten metal and silicate at high pressure and temperature. Geochim. Cosmochim. Acta 121, 15-28. https://doi.org/10.1016/j.gca.2013.07.007

Roskosz, M., Mysen, B.O., Cody, G.D., 2006. Dual speciation of nitrogen in silicate melts at high pressure and temperature: An experimental study. Geochim. Cosmochim. Acta 70, 29022918. https://doi.org/10.1016/j.gca.2006.03.001 
Shishkina, T.A., Botcharnikov, R.E., Holtz, F., Almeev, R.R., Portnyagin, M.V., 2010. Solubility of H2Oand $\mathrm{CO}$-bearing fluids in tholeiitic basalts at pressures up to 500MPa. Chem. Geol. 277, 115125. https://doi.org/10.1016/j.chemgeo.2010.07.014

Speelmanns, I.M., Schmidt, M.W., Liebske, C., 2019. The almost lithophile character of nitrogen during core formation. Earth Planet. Sci. Lett. 510, 186-197. https://doi.org/10.1016/j.epsl.2019.01.004

Speelmanns, I.M., Schmidt, M.W., Liebske, C., 2018. Nitrogen Solubility in Core Materials. Geophys. Res. Lett. 45, 7434-7443. https://doi.org/10.1029/2018GL079130

Taylor, J.R., Wall, V.J., Pownceby, M.I., 1992. The calibration and application of accurate redox sensors. Am. Mineral. 77, 284-295.

Wood, B.J., Walter, M.J., Wade, J., 2006. Accretion of the Earth and segregation of its core. Nature 441, 825-833. https://doi.org/10.1038/nature04763

Woodland, A.B., O'Neill, H.St.C., 1997. Thermodynamic data for Fe-bearing phases obtained using noble metal alloys as redox sensors. Geochim. Cosmochim. icta 61, 4359-4366.

Yoshioka, T., Wiedenbeck, M., Shcheka, S., Keppler, H., 2018. Nitrogen -olubility in the deep mantle and the origin of Earth's primordial nitrogen budget. Earth Pla, ot. Sci. Lett. 488, 134-143. https://doi.org/10.1016/j.epsl.2018.02.021

Zahnle, K., Schaefer, L., Fegley, B., 2010. Earth's Earliest Atmos, hert s. Cold Spring Harb. Perspect. Biol. 2, a004895-a004895. https://doi.org/10.1101/: hperspect.a004895

Zolotov, M.Yu., 2011. On the chemistry of mantle and ma', $11 \mathrm{l}+$ ic volatiles on Mercury. Icarus 212, 2441. https://doi.org/10.1016/j.icarus.2010.12.014

Zolotov, M.Yu., Sprague, A.L., Hauck, S.A., Nittler, L.R.. Sciomo.i, S.C., Weider, S.Z., 2013. The redox state, FeO content, and origin of sulfur-rich $\mathrm{n}$ - gi nas on Mercury: SULFUR-RICH MAGMAS ON MERCURY. J. Geophys. Res. Planets 118, 1 i8-ío. https://doi.org/10.1029/2012JE004274 
Table 1. Experimental conditions and starting mixtures of the runs presented in this study. 'A' stands for internally heated pressure vessel experiments and 'PC' for piston cylinder experiments. A Cobalt Palladium (CoPd) sensor was used for the experiments with the highest $\mathrm{PH}_{2}$ pressure, whereas a Nickel Palladium (NiPd) sensor was used for low- $\mathrm{PH}_{2}$ experiments.

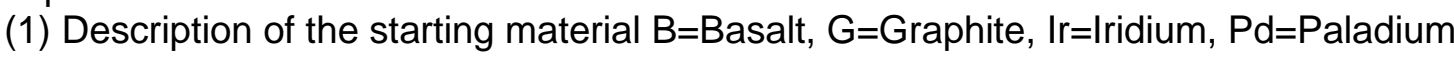

\begin{tabular}{|c|c|c|c|c|c|c|c|c|c|c|c|}
\hline Run & Sample ID & Starting material ${ }^{(1)}$ & $\begin{array}{c}\text { Duration } \\
\text { (hour) }\end{array}$ & $\begin{array}{c}\mathrm{N} \\
(\mathrm{wt} \%)\end{array}$ & $\begin{array}{l}\mathrm{H}_{2} \mathrm{O} \\
\text { (wt\%) }\end{array}$ & $\begin{array}{c}\mathrm{C} \\
(w t \%)\end{array}$ & $\begin{array}{c}\text { Type } \\
\text { capsule }\end{array}$ & $\begin{array}{c}\mathrm{T} \\
\left({ }^{\circ} \mathrm{C}\right)\end{array}$ & $\mathrm{P}$ (bar) & $\begin{array}{l}\mathrm{fH}_{2} \\
\text { (bar) }\end{array}$ & $\begin{array}{c}\text { External } \\
\text { sensor }\end{array}$ \\
\hline \multirow[t]{3}{*}{ A RUN 1} & AR1FeN & $\mathrm{B}+\mathrm{Fe} 3,5 \mathrm{~N}$ & 1 & 0.67 & - & - & AuPd & 1200 & 800 & 10 & CoPd \\
\hline & AR1HNO3C & $\mathrm{B}+\mathrm{HNO} 3+\mathrm{G}$ & 1 & 1.44 & 3.5 & 10.0 & AuPd & 1200 & 800 & 10 & CoPd \\
\hline & AR1NH3 & $\mathrm{B}+\mathrm{NH} 3$ & 1 & 3.45 & 6.5 & - & AuPd & 1200 & 800 & 10 & CoPd \\
\hline \multirow[t]{3}{*}{ A RUN 3} & AR3FeNFeS & $\mathrm{B}+\mathrm{Fe} 3,5 \mathrm{~N}+\mathrm{FeS}$ & 1 & 0.33 & - & ( & $\mathrm{Pt}$ & 1200 & 800 & 5 & $\mathrm{NiPd}$ \\
\hline & AR3HNO3C & $\mathrm{B}+\mathrm{HNO} 3+\mathrm{G}$ & 1 & 1.44 & 3.5 & & AuPd & 1200 & 800 & 5 & $\mathrm{NiPd}$ \\
\hline & AR3HNO3AgCO & $\mathrm{B}+\mathrm{HNO} 3+\mathrm{Ag} 2 \mathrm{CO} 4$ & 1 & 1.44 & 3.5 & u.v & AuPd & 1200 & 800 & 5 & $\mathrm{NiPd}$ \\
\hline \multirow[t]{2}{*}{ A RUN 4} & AR4NH3FeSCIr & $\mathrm{B}+\mathrm{NH} 3+\mathrm{FeS}+\mathrm{G}+\mathrm{Ir}$ & 1 & 3.45 & 6 & 7.0 & $\mathrm{Pt}$ & 1200 & 2400 & 24 & CoPd \\
\hline & AR4HNO3CPd & $\mathrm{B}+\mathrm{HNO} 3+\mathrm{G}+\mathrm{Pd}$ & 1 & 1.44 & & 7.0 & AuPd & 1200 & 2400 & 24 & CoPd \\
\hline \multirow[t]{2}{*}{ A RUN 5} & AR5SiNFeN & $\mathrm{B}+\mathrm{Si} 3 \mathrm{~N} 4+\mathrm{Fe} 3,5 \mathrm{~N}$ & 1 & 1.78 & & - & AuPd & 1300 & 900 & 10 & CoPd \\
\hline & AR5SiNFeNx2 & $\mathrm{B}+\mathrm{Si} 3 \mathrm{~N} 4+\mathrm{Fe} 3,5 \mathrm{~N}$ & 1 & 3. if & - & - & AuPd & 1300 & 900 & 10 & CoPd \\
\hline PC RUN 2 & PCR2SiNFeN & $\mathrm{B}+\mathrm{Si} 3 \mathrm{~N} 4+\mathrm{Fe} 3,5 \mathrm{~N}$ & 1 & 78 & - & - & $\mathrm{Pt}$ & 1300 & 10000 & - & - \\
\hline
\end{tabular}




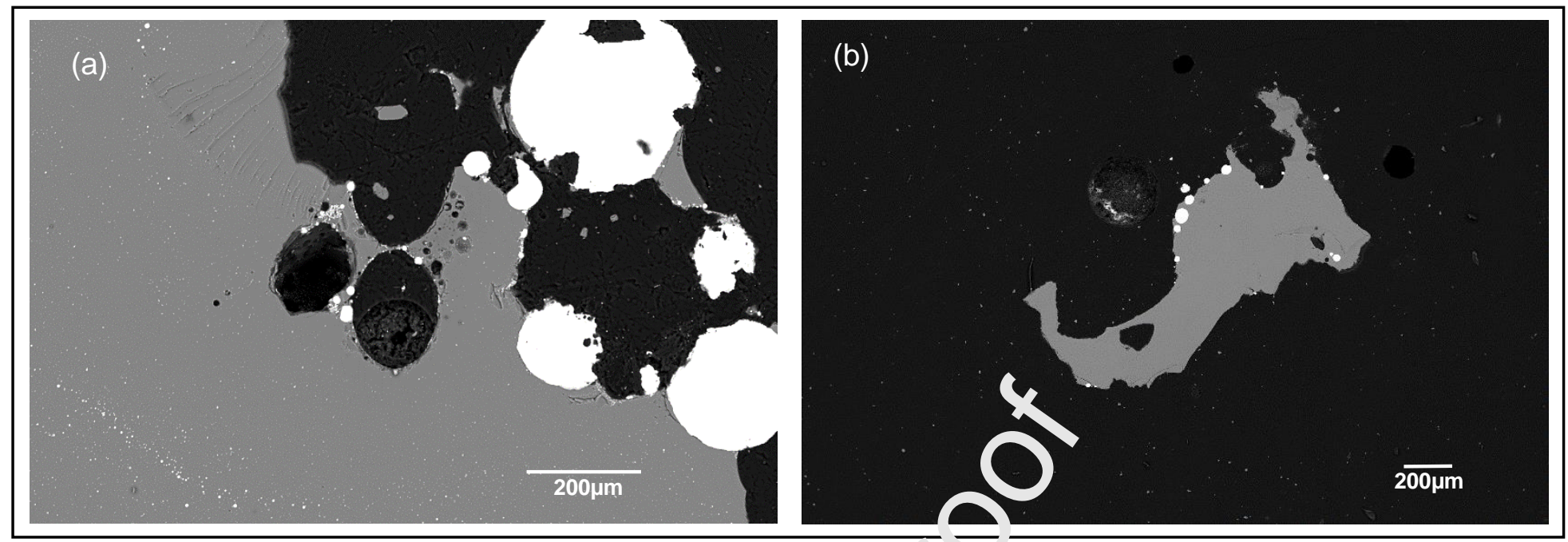

Figure. 1. Back scattered electron image (BSE) of (a) a part of the sample AR5SiNFeNx2 (Mag x177) with metal (white) and bubbles in the silic ate glass (grey). (b) A part of the sample AR5SiNFeN (Mag x35) with metal droplets i silicate glass and bubbles. For the most reduced sample (AR5SiNFeNx2) with $\mathrm{fO}_{-}$- IW-3.5 the formation of micronuggets was observed (a). 
Table 2. Chemical compositions (wt\%) silicate glasses and alloys determined by EPMA.

\begin{tabular}{|c|c|c|c|c|c|c|}
\hline & $\mathrm{AR} 1 \mathrm{HNO}_{3} \mathrm{C}$ & $1-\sigma$ & $\mathrm{AR}_{4} \mathrm{NH}_{3} \mathrm{FeSCIr}$ & $1-\sigma$ & $\mathrm{AR} 4 \mathrm{HNO}_{3} \mathrm{CPd}$ & $1-\sigma$ \\
\hline $\mathrm{SiO}_{2}$ & 48,36 & 0,09 & 45,99 & 0,26 & 47,13 & 1,02 \\
\hline $\mathrm{TiO}_{2}$ & 1,67 & 0,12 & 1,46 & 0,13 & 1,40 & 0,12 \\
\hline $\mathrm{Al}_{2} \mathrm{O}_{3}$ & 14,70 & 0,12 & 14,28 & 0,09 & 13,49 & 0,24 \\
\hline $\mathrm{FeO}$ & 6,40 & 0,43 & 7,48 & 0,16 & 8,23 & 0,23 \\
\hline $\mathrm{MnO}$ & 0,15 & 0,02 & 0,14 & 0,07 & 0,12 & 0,05 \\
\hline $\mathrm{MgO}$ & 8,37 & 0,13 & 8,55 & 0,05 & 8,24 & 0,11 \\
\hline $\mathrm{CaO}$ & 12,57 & 0,28 & 11,12 & 0,16 & 10,82 & 0,18 \\
\hline $\mathrm{Na}_{2} \mathrm{O}$ & 3,49 & 0,12 & 3,18 & 0,03 & 3,21 & 0,12 \\
\hline $\mathrm{K}_{2} \mathrm{O}$ & 1,22 & 0,08 & 1,25 & 0,08 & 1,31 & 0,06 \\
\hline \multirow[t]{2}{*}{ Total } & 96,91 & 0,40 & 94,08 & 0,41 & 93,97 & 0,70 \\
\hline & $\mathrm{AR}_{1} \mathrm{HNO}_{3} \mathrm{C}$ & $1-\sigma$ & $\mathrm{AR}_{4} \mathrm{NH}_{3} \mathrm{FeSCIr}$ & $1-\sigma$ & $1 \mathrm{R}_{4} \mathrm{HNO}_{3} \mathrm{CPd}$ & $1-\sigma$ \\
\hline $\mathrm{Si}$ & 0,53 & 0,57 & 0.01 & 0.01 & 0.52 & 0.54 \\
\hline$P$ & - & - & - & & 0.01 & 0.01 \\
\hline S & - & - & 1.38 & $\therefore 70$ & 0.00 & 0.00 \\
\hline $\mathrm{Fe}$ & 22,29 & 0,35 & 3.52 & 1,4 & 10.53 & 0.21 \\
\hline $\mathrm{Pd}$ & 77,02 & 1,94 & 0.00 & 0.60 & 84.66 & 2.05 \\
\hline $\mathrm{Pt}$ & - & - & 0.00 & 0.00 & 0.22 & 0.32 \\
\hline Ir & - & - & 8151 & 5.14 & - & - \\
\hline \multirow[t]{2}{*}{ Total } & 99,85 & 1,54 & 89. 7 & 3.37 & 95.94 & 1.97 \\
\hline & AR5SiNFeN & $1-\sigma$ & Ar. 'SiNFeNx2 & $1-\sigma$ & PCR2SiNFeN & $1-\sigma$ \\
\hline $\mathrm{SiO}_{2}$ & 52,99 & 0,85 & $j 6,71$ & 0,76 & 54,85 & 0,38 \\
\hline $\mathrm{TiO}_{2}$ & 1,49 & 0,07 & 0,79 & 0,20 & 1,44 & 0,05 \\
\hline $\mathrm{Al}_{2} \mathrm{O}_{3}$ & 14,80 & 0,$2 ;$ & 14,96 & 0,21 & 14,83 & 0,15 \\
\hline $\mathrm{FeO}$ & 2,66 & 0,92 & 0,46 & 0,15 & 1,61 & 0,35 \\
\hline $\mathrm{MnO}$ & 0,16 & $? .05$ & 0,18 & 0,05 & 0,18 & 0,07 \\
\hline $\mathrm{MgO}$ & 9,11 & $?, 16$ & 9,19 & 0,27 & 9,17 & 0,14 \\
\hline $\mathrm{CaO}$ & 11,85 & 0,23 & 11,90 & 0,27 & 11,84 & 0,19 \\
\hline $\mathrm{Na}_{2} \mathrm{O}$ & 3,31 & 0,22 & 3,31 & 0,10 & 3,41 & 0,09 \\
\hline $\mathrm{K}_{2} \mathrm{O}$ & 1,30 & 0,08 & 1,29 & 0,09 & 1,32 & 0,04 \\
\hline \multirow[t]{2}{*}{ Total } & 97,88 & 0,58 & 98,82 & 0,63 & 98,84 & 0,57 \\
\hline & AR5SiNFeN & $1-\sigma$ & AR5SiNFeNx2 & $1-\sigma$ & PCR2SiNFeN & $1-\sigma$ \\
\hline$\overline{\mathrm{Si}}$ & 0.01 & 0.01 & 0,01 & 0,01 & 0,01 & 0,01 \\
\hline$P$ & 3.85 & 1.83 & 3,09 & 1,95 & 6,04 & 3,96 \\
\hline S & 0.01 & 0.01 & 0,01 & 0,01 & 0,01 & 0,01 \\
\hline $\mathrm{Fe}$ & 91.06 & 1.77 & 91,39 & 1,58 & 90,08 & 2,83 \\
\hline $\mathrm{Pd}$ & 0.01 & 0.02 & 0,01 & 0,01 & 0,00 & 0,00 \\
\hline $\mathrm{Pt}$ & 0.00 & 0.00 & 0,00 & 0,00 & 0,00 & 0,00 \\
\hline Ir & - & - & - & - & - & - \\
\hline Total & 94.95 & 0.45 & 94,51 & 0,67 & 96,15 & 1,23 \\
\hline
\end{tabular}




\begin{tabular}{|c|c|c|c|c|c|c|}
\hline & AR1FeN & $1-\sigma$ & $\mathrm{AR}_{1} \mathrm{NH}_{3} \mathrm{C}$ & $1-\sigma$ & $\mathrm{AR} 3 \mathrm{HNO}_{3} \mathrm{AgCO}$ & $1-\sigma$ \\
\hline $\mathrm{SiO}_{2}$ & 48,15 & 0,38 & 47.33 & 0.81 & 45,86 & 0,50 \\
\hline $\mathrm{TiO}_{2}$ & 1,64 & 0,10 & 1.59 & 0.14 & 1,36 & 0,10 \\
\hline $\mathrm{Al}_{2} \mathrm{O}_{3}$ & 14,67 & 0,19 & 15.11 & 0.33 & 13,81 & 0,10 \\
\hline $\mathrm{FeO}$ & 6,12 & 0,24 & 5.68 & 1.16 & 9,23 & 0,25 \\
\hline $\mathrm{MnO}$ & 0,16 & 0,04 & 0.23 & 0.03 & 0,09 & 0,06 \\
\hline $\mathrm{MgO}$ & 8,39 & 0,08 & 7.66 & 0.10 & 8,46 & 0,03 \\
\hline $\mathrm{CaO}$ & 11,62 & 0,08 & 12.44 & 0.22 & 10,75 & 0,18 \\
\hline $\mathrm{Na}_{2} \mathrm{O}$ & 3,76 & 0,04 & 3.83 & 0.21 & 3,31 & 0,09 \\
\hline $\mathrm{K}_{2} \mathrm{O}$ & 1,37 & 0,04 & 1.22 & 0.11 & 1,27 & 0,08 \\
\hline \multirow[t]{2}{*}{ Total } & 95,87 & 0,62 & 95.10 & 0.35 & 94,15 & 0,68 \\
\hline & AR3FeNFeS & $1-\sigma$ & $\mathrm{AR}_{3} \mathrm{HNO}_{3} \mathrm{C}$ & $1-\sigma$ & & \\
\hline $\mathrm{SiO}_{2}$ & 48.36 & 0.19 & 46,79 & 0,21 & & \\
\hline $\mathrm{TiO}_{2}$ & 1.42 & 0.15 & 1,53 & 0,00 & & \\
\hline $\mathrm{Al}_{2} \mathrm{O}_{3}$ & 15.48 & 0.09 & 14,08 & 01 & & \\
\hline $\mathrm{FeO}$ & 9.27 & 0.41 & 9,00 & 0,21 & & \\
\hline $\mathrm{MnO}$ & 0.18 & 0.08 & 0,20 & 0,19 & & \\
\hline $\mathrm{MgO}$ & 6.66 & 0.09 & 8,73 & 0.17 & & \\
\hline $\mathrm{CaO}$ & 11.47 & 0.11 & 11,26 & 0,19 & & \\
\hline $\mathrm{Na}_{2} \mathrm{O}$ & 3.53 & 0.06 & 3,34 & 0,07 & & \\
\hline $\mathrm{K}_{2} \mathrm{O}$ & 1.43 & 0.05 & $1,<)$ & 0,07 & & \\
\hline Total & 97.80 & 0.43 & $\therefore 13$ & 0,30 & & \\
\hline
\end{tabular}


Table 3. Volatile concentrations in the silicate melt as a function of $\mathrm{fO}_{2}(\Delta \mathrm{IW})$.

(1) Description of the run product, $\mathrm{G}=\mathrm{Glass}, \mathrm{Bbl}=\mathrm{Bubble}, \mathrm{Cr}=$ Crystals, $\mathrm{A}=\mathrm{Alloy}, \mathrm{C}=\mathrm{Graphite}$

\begin{tabular}{|c|c|c|c|c|c|c|c|c|c|}
\hline Run & Name & $\begin{array}{c}\log \mathrm{fO}_{2} \\
(\Delta \mathrm{IW})\end{array}$ & $\begin{array}{c}\mathrm{N} \text { glass } \\
\text { (ppm) }\end{array}$ & Err & $\begin{array}{l}\mathrm{H}_{2} \mathrm{O} \\
\text { (wt\%) }\end{array}$ & Err & $\mathrm{CO}_{2}(\mathrm{wt} \%)$ & Err & Run product description \\
\hline \multirow[t]{3}{*}{ A RUN 1} & AR1FeN & 1.59 & 20.86 & 4.23 & 0.62 & 0.08 & - & - & $\mathrm{G}+\mathrm{Bbl}+\mathrm{Cr}$ \\
\hline & AR1HNO3C & 2.18 & 9.27 & 2.80 & 0.42 & 0.02 & - & - & $\mathrm{G}+\mathrm{Bbl}+\mathrm{Cr}+\mathrm{A}+\mathrm{C}$ \\
\hline & AR1NH3 & 3.10 & 3.62 & 1.88 & 1.69 & 0.09 & - & - & $\mathrm{G}+\mathrm{Bbl}$ \\
\hline \multirow[t]{3}{*}{ A RUN 3} & AR3FeNFes & 3.71 & 20.08 & 4.08 & 1.01 & 0.03 & - & - & $\mathrm{G}+\mathrm{Bbl}$ \\
\hline & AR3HNO3C & 4.21 & 7.04 & 2.13 & 1.44 & 0.06 & 0.01 & 0.0028 & $\mathrm{G}+\mathrm{Bbl}+\mathrm{C}$ \\
\hline & AR3HNO3AgCO & 4.91 & 3.94 & 2.04 & 2.32 & 0.05 & - & - & $\mathrm{G}+\mathrm{Bbl}$ \\
\hline \multirow[t]{2}{*}{ A RUN 4} & AR4NH3FeSCIr & 2.41 & 17.49 & 3.57 & 1.69 & 0.15 & 0.02 & - & $\mathrm{G}+\mathrm{Bbl}+\mathrm{A}+\mathrm{S}+\mathrm{C}$ \\
\hline & AR4HNO3CPd & 3.08 & 26.26 & 5.33 & 2.76 & C.vo & 0.08 & 0.0096 & $\mathrm{G}+\mathrm{Bbl}+\mathrm{A}+\mathrm{C}$ \\
\hline \multirow[t]{2}{*}{ A RUN 5} & AR5SiNFeN & -2.94 & 93 & 3 & 0.04 & h & - & - & $\mathrm{G}+\mathrm{Bbl}+\mathrm{A}$ \\
\hline & AR5SiNFeNx2 & -4.72 & 1737 & 112 & $0.0 ?$ & 0.01 & - & - & $\mathrm{G}+\mathrm{Bbl}+\mathrm{A}$ \\
\hline PC RUN 2 & PCR2SiNFeN & -2.95 & 1504 & 34 & 1.05 & 0.01 & - & - & $\mathrm{G}+\mathrm{Bbl}+\mathrm{A}$ \\
\hline
\end{tabular}


Table 4. The calculated fluid mixture in equilibrium with the different samples during the

\begin{tabular}{c|ccccccccc}
\hline RUN & Name & Pressure (bar) & $\mathrm{fH}_{2} \mathrm{O}$ & $\mathrm{Err}$ & $\mathrm{fCO}_{2}$ & $\mathrm{Err}$ & $\mathrm{fCO}$ & $\mathrm{fH}_{2}$ & $\mathrm{fN}_{2}$ \\
\hline A RUN 1 & AR1FeN & 800 & 49 & 6 & - & - & - & 10 & 741 \\
A RUN 1 & AR1HNO3C & 800 & 97 & 4 & - & - & - & 10 & 693 \\
A RUN 1 & AR1Li\&K & 800 & 278 & 15 & - & - & - & 10 & 512 \\
A RUN 3 & AR3FeNFeS & 800 & 112 & 2 & - & - & - & 5 & 683 \\
A RUN 3 & AR3HNO3C & 800 & 200 & 8 & 300 & 71 & 0.25 & 5 & 295 \\
A RUN 3 & AR3HNO3AgCO & 800 & 448 & 10 & - & - & - & 5 & 347 \\
A RUN 4 & AR4NH3FeSCIr & 2400 & 300 & 10 & 305 & 116 & 0.03 & 24 & 1771 \\
A RUN 4 & AR4HNO3CPd & 2400 & 732 & 21.6 & 504 & 59.2 & 0.01 & 24 & 1140 \\
A RUN 5 & AR5SiNFeN & 900 & 1 & 0.4 & - & - & - & 9 & 890 \\
A RUN 5 & AR5SiNFeNx2 & 900 & 0 & 0.03 & - & - & - & 9 & 891 \\
PC RUN 2 & PCR2SiNFeN & 10000 & - & - & - & & - & - & 56000 \\
experiment. & & & & & & & &
\end{tabular}


Table 5. Comparison between the different calculated log fO2 ( $\Delta \mathrm{IW})$. (1) Sensor calculation,(2) Fe-FeO calculation (equilibrium (6)), (3) $\mathrm{H} 2-\mathrm{H} 2 \mathrm{O}$ calculation (equilibrium (9))

\begin{tabular}{|c|c|c|c|c|c|c|}
\hline Run & Name of sample & External $\log \mathrm{fO}_{2}(1)$ & Internal $\log \mathrm{fO}_{2}(\mathrm{FeO})^{(2)}$ & Err & Internal $\log \mathrm{fO}_{2}\left(\mathrm{H}_{2} \mathrm{O}\right)^{(3)}$ & Err \\
\hline A Run 1 & AR1FeN & \multirow{3}{*}{3.39} & - & - & 1.59 & 0.12 \\
\hline A Run 1 & AR1HNO3C & & 1.97 & 0.07 & 2.18 & 0.04 \\
\hline A Run 1 & AR1Li\&K & & - & - & 3.10 & 0.05 \\
\hline A Run 3 & AR3FeNFeS & \multirow{3}{*}{4.40} & - & - & 3.71 & 0.02 \\
\hline A Run 3 & AR3HNO3C & & - & - & 4.21 & 0.04 \\
\hline A Run 3 & AR3HNO3AgCO & & - & - & 4.91 & 0.02 \\
\hline A Run 4 & AR4NH3FeSCIr & \multirow{2}{*}{3.80} & 2.47 & 0.09 & 2.41 & 0.03 \\
\hline A Run 4 & AR4HNO3CPd & & 2.91 & 0.03 & 3.08 & 0.03 \\
\hline A Run 5 & AR5SiNFeN & & -2.53 & 0.20 & -2.94 & 0.37 \\
\hline A Run 5 & AR5SiNFeNx2 & & -4.50 & 0.8 & -4.72 & 0.43 \\
\hline PC Run 2 & PCR2SiNFeN & - & -2.95 & $n 10$ & - & - \\
\hline
\end{tabular}




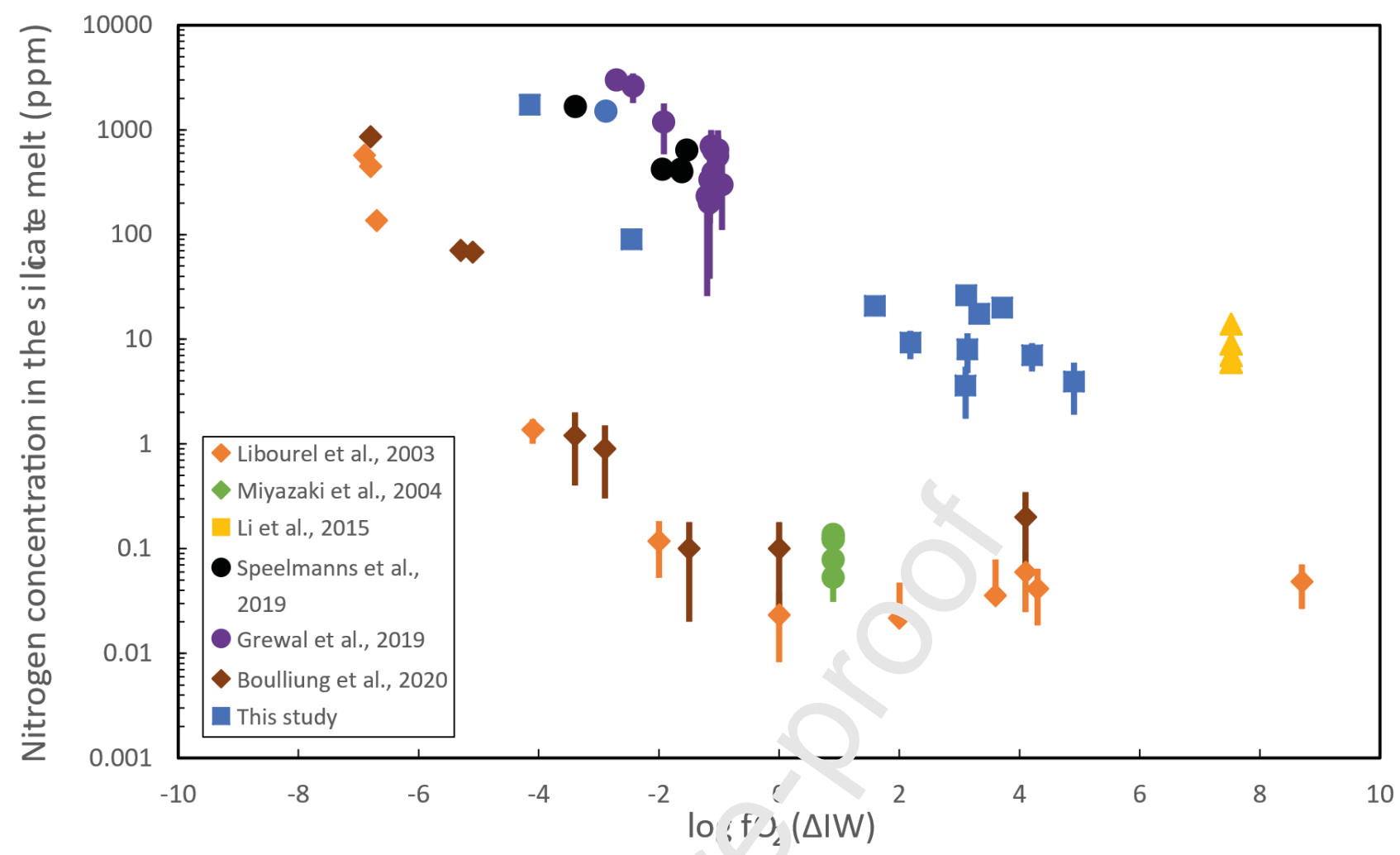

Figure. 2. Nitrogen concentration in $\mathrm{v}_{\mathrm{i}}$ saltic silicate melt as a function of the $\mathrm{fO}_{2}(\Delta \mathrm{IW})$. Comparison of our experimental $\mathrm{r}$ sI / 1800 [blue square] to 10000 bar [blue circle]) with result of low-pressure study (ie. ' ihc "2l et al. 2003, Miyazaki et al. 2004, Boulliung et al. 2020; 1 bar) and high pressure s' 'idy ie. Grewal et al. 2019, Speelmanns et al. $2019>10000$ bar) 


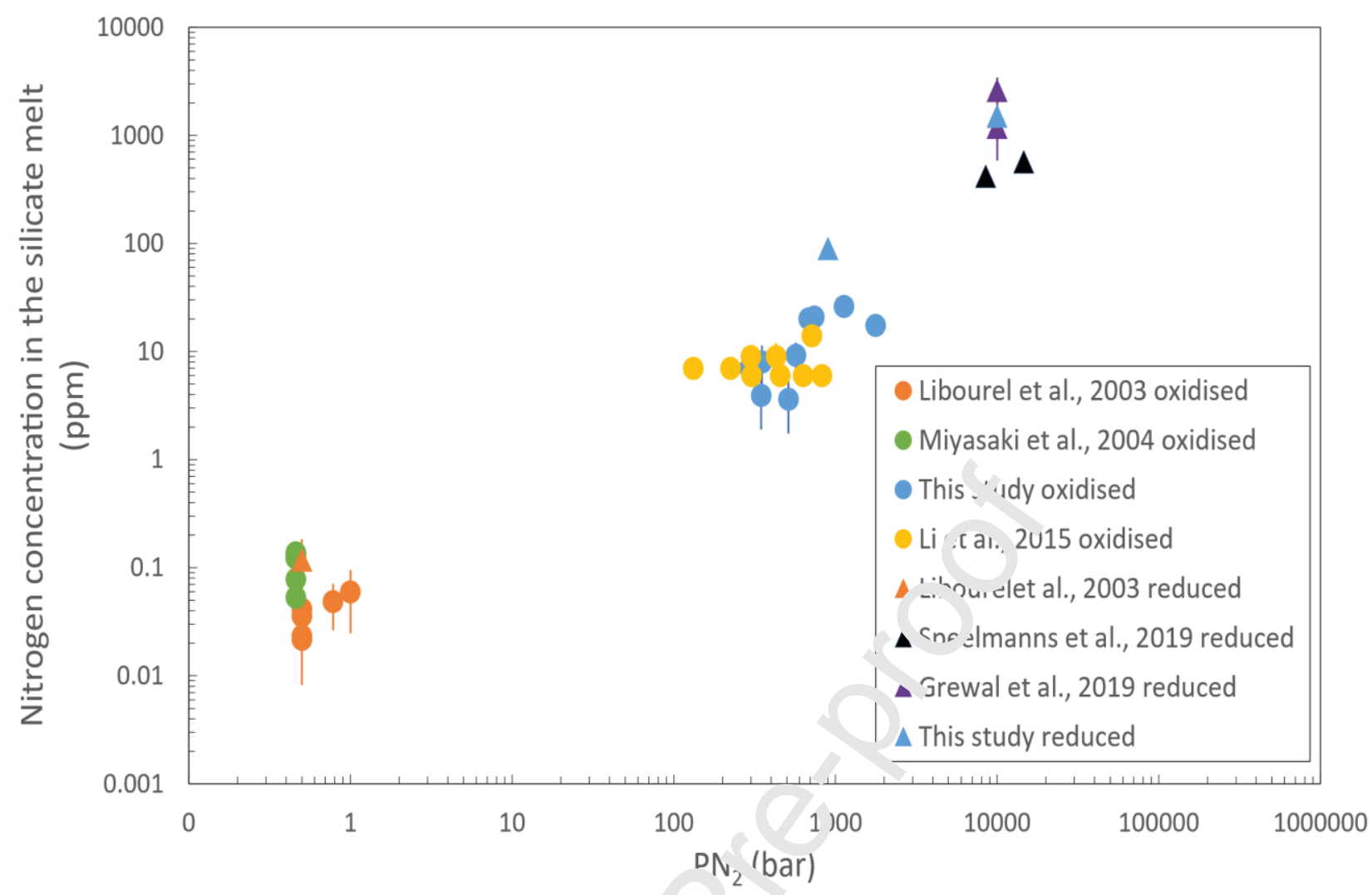

Figure. 3. Nitrogen concentration a, fu.nction of the nitrogen pressure. Result of oxidised experiments $\left(\log \mathrm{fO}_{2}>\mathrm{IW}\right)$ are show $\mathrm{w}_{11}$, w ere the effect of the pressure is the clearest due to the limited impact of the $\mathrm{fO}_{2}$. For mu: ? reduced conditions than IW, we select only data at log $\mathrm{fO}_{2} \approx \mathrm{IW}-2$ in order to limit the st or 1 effect of the $\mathrm{fO}_{2}$ and identify the real impact of the $P\left(\mathrm{~N}_{2}\right)$. 
Table 6. Thermodynamic constants of the model adjusted with the database

\begin{tabular}{c|c|c|c|c|c}
$\Delta \mathrm{H}_{13}\left(\mathrm{~J} . \mathrm{mol}^{-1}\right)$ & $\Delta \mathrm{S}_{13}\left(\mathrm{~J} . \mathrm{K}_{\mathrm{mol}}{ }^{-1}\right)$ & $\Delta \mathrm{V}_{13}(\mathrm{~J} /$ bar $)$ & $\Delta \mathrm{H}_{14}\left(\mathrm{~J} . \mathrm{mol}^{-1}\right)$ & $\Delta \mathrm{S}_{14}\left(\mathrm{~J} . \mathrm{K}_{\mathrm{mol}}{ }^{-1}\right)$ & $\Delta \mathrm{V}_{14}(\mathrm{~J} / \mathrm{bar})$ \\
\hline $29344_{-7336}^{+5868}$ & $-121_{-6}^{+4}$ & $4_{-0.9}^{+0.6}$ & $183733_{-919}^{+551}$ & $-172_{-0.2}^{+0.2}$ & $-5_{-0.06}^{+0.25}$
\end{tabular}



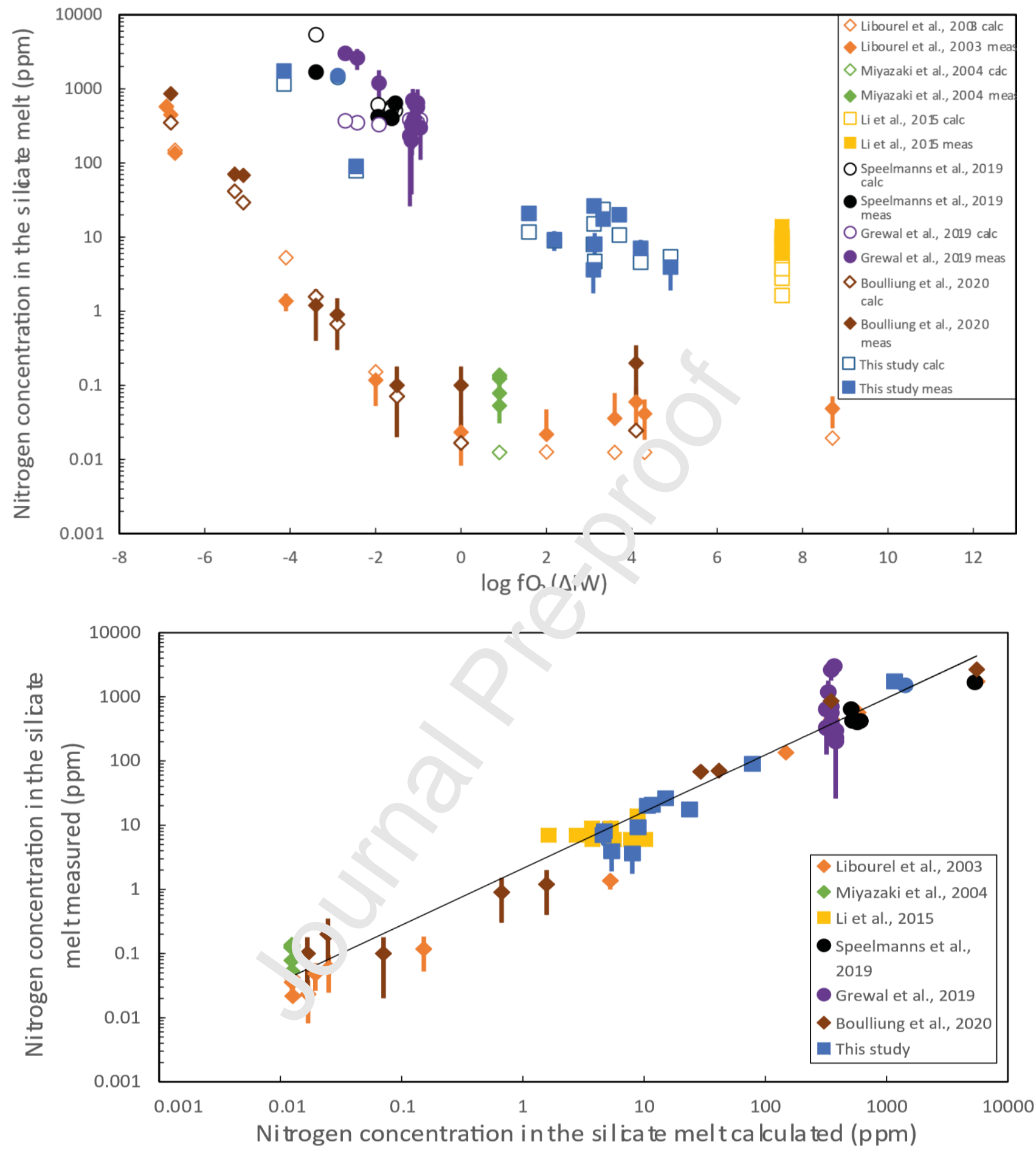

Figure. 4. Top diagram shows the difference between the measured nitrogen concentrations from different studies (full symbols) with the nitrogen concentration calculated by the model for identical conditions (open symbols) as a function of $\mathrm{fO}_{2}$. Second diagram at the bottom is a plot of measured versus calculated nitrogen concentration in the silicate melt. These two diagrams highlight the reproducibility of the data obtained experimentally by the model for identical conditions. 


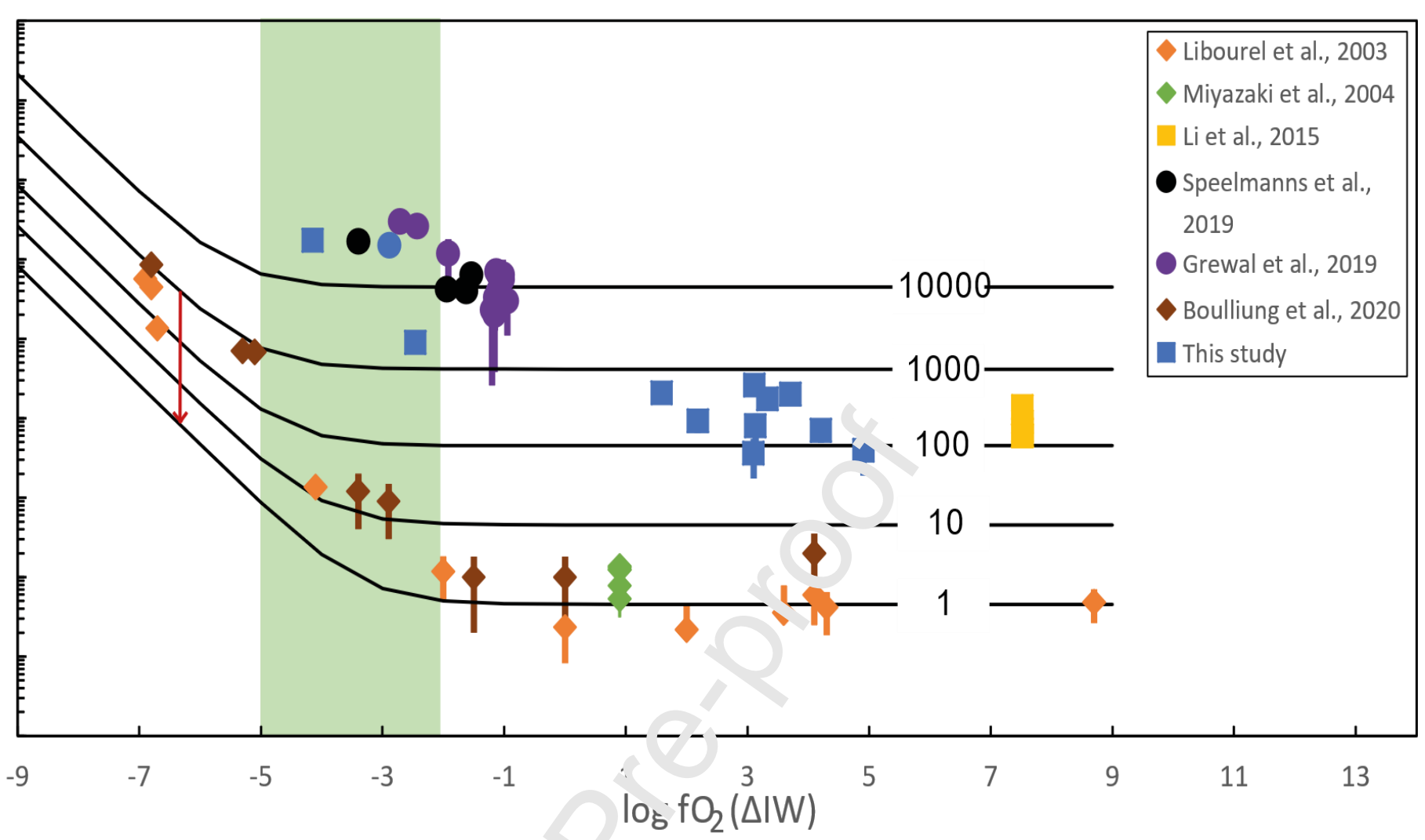

Figure. 5. Nitrogen fugacity isobars $(\mathrm{k}$ ar , report on a nitrogen concentration diagram as a function oxygen fugacity. Use of 'su' silicate melt vary with the press $\lambda$, combine to the oxygen fugacity. All the data use in this study was report. Green rectany'e represents the interval of magma ocean redox conditions. Red arrow corresponds to the $v^{-1}$ canic degassing scenario of mercury discuss in 4.4. 


\section{Declaration of interests}

$\otimes$ The authors declare that they have no known competing financial interests or personal

relationships that could have appeared to influence the work reported in this paper.

$\square$ The authors declare the following financial interests/personal relationships which may be considered as potential competing interests: 